\title{
REVISION OF THE CHARACEAE (CHARALES, CHAROPHYCEAE) SPECIES AND THEIR DISTRIBUTION IN LITHUANIA
}

\author{
Zofija SINKevičIENĖ*, Zigmantas GUDŽInSKaS
}

Nature Research Centre, Institute of Botany, Žaliųų Ežerų Str. 49, 12200 Vilnius, Lithuania

*Corresponding author. E-mail: zofija.sinkeviciene@gamtc.lt

\begin{abstract}
Sinkevičienė Z., Gudžinskas Z., 2021: Revision of the Characeae (Charales, Charophyceae) species and their distribution in Lithuania. - Botanica, 27(2): 95-124.

The current inventory was mainly based on revising herbarium specimens collected since the 19th century and confirmed twenty-one Characeae species in Lithuania. They are representatives of five genera: Chara (12 species), Nitella (5), Tolypella (2), Lychnothamnus and Nitellopsis (by one species each). Thirteen species mentioned in references or labels of herbarium specimens were not confirmed. The occurrence of the Characeae species was recorded in 251 map grid cells ( $42 \%$ of the total number 593). Herbarium specimens were collected from 693 water bodies, mainly lakes. Chara globularis was the most common species, recorded in 150 map grid cells and more than 250 water bodies. Ten species (C. aspera, C. contraria, C. filiformis, C. subspinosa, C. tomentosa, C. virgata, C. vulgaris, Nitella mucronata, N. flexilis, Nitellopsis obtusa) were recorded in the interval from 100 to 50 grid cells and also belong to the group of common species. Chara papillosa and C. strigosa were recorded less than in 50 grid cells and should be considered quite common. Eight species (C. baltica, C. canescens, Lychnothamnus barbatus, Nitella confervacea, N. gracilis, N. syncarpa, Tolypella nidifica, T. prolifera) were recorded in ten or fewer grid cells and belong to the group of rare or very rare species. The occurrence of species that have not been confirmed by the herbarium specimens was discussed.
\end{abstract}

Keywords: Chara, Characeae, distribution maps, herbarium, Lychnothamnus, Nitella, Nitellopsis, Tolypella.

\section{INTRODUCTION}

Charophytes have rarely been considered the main study object during the history of investigations on the flora of Lithuania; however, this group of plants has never been omitted because of their importance in the aquatic vegetation. First data on the Characeae species were published late in the 18th century, when JunDziŁt (1791) listed Chara tomentosa L., C. vulgaris L. and C. hispida $\mathrm{L}$. in the common account of plant species occurring or capable of occurring on the territory formerly significantly larger than present-day Lithuania. The focus on aquatic plants, and charophytes among them, increased in the first half of the 19th century. The significant contributions were made by J.B. Wolfgang (1777-1859) and S.B. Gorski (1802-1682), pharmacists of Vilnius Academy of Medicine and
Surgery, (Mowszowicz, 1947). At that time, floristic investigations were concentrated mainly in the environs of Vilnius. Abundant herbarium material was collected, and the results of numerous botanical excursions were published in the local journals "Pamiętnik Farmaceutyczny", and "Dziennik Mediciny, Chirurgii i Farmacii". Information about the collected Characeae species, often unidentified, was also announced. WoLFGANG (1824) published a report about 26 Characeae species described, and their illustrations were prepared for publication. Possibly, the Characeae were the part of the monograph (together with Potamogeton) prepared by J.X. Wolfgang, whose manuscript was sent to the Russian Society of Nature Explorers; however, it has never been published (Mowszowicz, 1957). The most comprehensive list on the Characeae, published by Gorski (1830), included eight species 
(C. ceratophylla Wallr., C. vulgaris L., C. flexilis L., C. pulchella Wallr., C. funicularis Pers., C. batrachosperma Pers., C. brachiata Dierb., C. aspera DC.) with short notes on their habitats and distribution. Botanist J. Jundziłł (JunDzIEt, 1822, 1830) reported a few charophytes in the western part of the country. This promising period of floristic research was interrupted by the closure of Vilnius Imperial University in 1832 and finally of the Academy of Medicine and Surgery in 1842. The last effort to publish data about rare and new aquatic species in the issue "Icones Potamogetonum, Characearum, Cyperacearum et Graminearum novas vel minus cognitas species Lithuaniae illustrantes" by GoRsKi (1849) was also unsuccessful. The study was published incompletely (only Tables) and subsequently was lost (HRYNIEWIECKI, 1959-1960). The Wroblewski Library of the Lithuanian Academy of Sciences stores microfilm of 20 tables with plants depicted by S.B. Gorski. Pictures of charophytes were presented on nine tables (Gorski, 1849; Tables IXXVII). The microfilm has been received from the Library of the Kraków Academy of Sciences (GALINIS, 1968). A large part of the Charophyte herbarium from this period was transferred to Kyiv (recently National Herbarium of Ukraine; KW); however, the envelope with macroalgae specimens from the historical W. Besser's collection was lost, most probably during World War II. A part of the Charophyte collection, usually called "Herbarium of Gorski", including about 450 specimens collected mainly in 1823 , has survived and currently is stored at the Herbarium of Vilnius University (WI). This collection has been studied and described particularly by Mowszowicz (1947) and MinKevičius \& TRainausKaitė (1970).

After the closure of Vilnius Imperial University in 1832 and the Academy of Medicine and Surgery in 1842, Stefan Batory University was established only in 1919 and continued its activities until 1939 in Vilnius at the time being occupied by Poland. During this quite a short period, the investigations on the Characeae were only fragmentary. J. Mowszowicz (19011982) was mainly interested in studying the Characeae collection of the 19th century, and he collected the plants himself in the environs of Vilnius. Mowszowicz $(1947,1957)$ published a list of 19 Characeae species, mainly recorded around Vilnius city since the $19^{\text {th }}$ century, with a short history of their investigation. Of the 19 species described, the author indicated 15 species with collection dates; however, specimens were either poorly labelled or lost during the war. The Characeae findings from Trakai district lakes, reported by J. Matuszkiewiczówna (Matuszkiewiczówna, 1935) and J. Trzebińsky, were included in this species account. The specimens are stored in the WI Herbarium. The specimens collected by I. Dąbkowska from Švenčionys Region are deposited at the Algae Herbarium of Adam Mickiewicz University in Poznan (POZA).

In the middle of the 20th century, special investigations of the Characeae were initiated at Vilnius University by Professor A. Minkevičius (19001998). He was involved in this work with the students, doctoral students and other researchers of aquatic flora working at the University and the Institute of Biology (later Institute of Botany). The first doctoral theses about this group of algae in the water bodies of Lithuania was prepared and defended by Trainauskaité (1970). Many publications on the aquatic flora included data on the Characeae or were intended for the studies of this group in different water bodies such as lakes (Minkevičius, 1954; Minkevičius \& Trainauskaité, 1957; Mardosaitė \& MinkeviČIus, 1958; Bagdonaité, 1962; ŠarkinienĖ, 1961, 1968, 1969; ŠArkiniENĖ \& TrainausKaité, 1973; Trainauskaitė \& Šarkiniené, 1973; Trainauskaité et al., 1977; Trainauskaité, 1987; BALEVIČIENE \& ŠARKINIENĖ, 1988), the Curonian Lagoon (Minkevičius \& Pipinys, 1959; Trainauskaité, 1978) and water reservoirs (ŠARKINIENE, 1970, 1971). The first list of 16 Characeae species with the Lithuanian names was published by ŠARKINIENE (1961). The later checklists (TRAINAUSKaitĖ, 1970; ŠARKINIENE \& TrainausKaité, 1973) listed 24 species of the Characeae in Lithuanian water bodies.

A significant decline of the Characeae species in lakes affected by human activities has been observed during the last decades of the 20th century. For the first time, the Characeae species have been included in the Red Data Book (Trainauskaite, 1992; Š́ARKInIENĖ \& Trainauskaité, 1993). This has led to further studies of charophytes in the lakes of protected areas (SINKEVIČIENÉ, 1994; BALEVIČIENĖ \& BalevičIUS, 1994; BALEVIČIUS, 1994, 1998), in water bodies of urban territories (STEPANAVIČIENE, 2000), and has increased the focus on endangered species (SinKeVIČIENĖ, 1996; BaleVIČIUS, 2001; SinKEVIČIENĖ, 2007, 2010; SinkeviČIENĖ \& URbaitè-MaŽEviČ, 2012). 
Investigations on the vegetation of the Curonian Lagoon (PlokštienE, 2002) and the work related to the preparation of the monograph on charophytes of the Baltic Sea (Schubert \& Blindow, 2003) have added a brackish water species to the list of the Characeae (SINKEvičIENĖ, 2004). The updated Red List (SINKEVIČIENĖ, 2007) and the List of common Characeae species have been published (KosTKEVIČIENĖ \& SinKEVIČIENĖ, 2008).

A large amount of the data on charophytes have been collected during the investigations related to the implementation of the Directives of the European Union (Council Directive 92/43/EEC on the conservation of natural habitats and wild fauna and flora; hereafter, Habitat Directive, and Directive 2000/60/EC of the European Parliament and the Council establishing a framework for the Community action in the field of water policy; hereafter, Water Framework Directive), only a small part of which have been published. In the last decade, the research on charophytes of the Curonian Lagoon has been repeated (SINKEVIČIENĖ et al., 2017; BuČAs et al., 2019). This material has been used to evaluate the current distribution of the Characeae species, and the new red list of threatened charophyte species according to the IUCN criteria has been prepared (SINKEVIǏIENE, 2021).

Maps of the distribution of charophytes in Lithuania have mainly been compiled for red-listed species (Trainauskaitė, 1992; SinkeviČIENĖ, 2007, 2021), some brackish water species (SCHUBERT \& Blindow, 2003; SINKEVIČIENE et al., 2017) and Chara filiformis (SINKEVIČIENE, 2019). This work aimed to provide an updated list of the Characeae species, based on all available studied oldest and recent data, and maps of their past and present distribution.

\section{MATERIALS AND METHODS}

The analysis of the Characeae species occurrence and distribution in Lithuania was based on the revision of herbarium specimens deposited at the Herbarium of the Laboratory of Flora and Geobotany (Institute of Botany of the Nature Research Centre, BILAS) and the Herbarium of Vilnius University (WI). Old literature data, including a common species or data supported by herbarium specimens, were also used. Additional data on species distribution from 2013 to 2015 were obtained from the En- vironmental Protection Agency (ApLINKos APSAUgos agENTŪRA, 2013-2015a, b).

Species were identified using keys published by Gollerbach \& Krassavina (1983), Krause (1997), UrbaniaK \& GĄBKa (2014) and VAN DE Weyer (2016). The nomenclature of the Characeae species follows the issue Arbeitsgruppe Characeen Deutschlands (2016). The threat assessment for the rare Characeae species was performed following the IUCN Guidelines and Criteria (IUCN 2012, 2017).

Distribution maps of the Characeae species in Lithuania were compiled using a system of map grid cells. The grid cells were arranged according to the geographical coordinates with sides 6' latitude and 10' longitude. The area of grid cells varies from $116.5 \mathrm{~km}^{2}$ in the northern to $123.2 \mathrm{~km}^{2}$ in the southern part of Lithuania. All localities recorded in the same grid cell on the map were marked by a single symbol, reflecting the period of the record (Table 1). Maps of distribution were created employing Adobe Illustrator 9.0.2 CE software.

Three periods of studies were distinguished for distribution mapping. The first period (1790-1850) coincided with the work of Vilnius Imperial University in 1803-1832 and the Academy of Medicine and Surgery in 1832-1842 after the University closure. Professors pharmacists of Vilnius Academy of Medicine and Surgery J.B. Wolfgang (1777-1859) and S.B. Gorski (1802-1682) were the leading collectors and determinators of the Characeae. Their publications, herbarium specimens and publications about Charophyte specimens from this period (Mowszowicz, 1947, 1957; MinKEVIČIUS \& TRAINAUSKAITÉ, 1970) were also used.

The second period (1919-1990) consisted of two stages. The first stage of 1919-1939 was linked with the Polish time and work of Stefan Batory University (1919-1939) in Vilnius, which was interrupted by World War II. Quite fragmentary material collected or published by J. Matuszkiewiczówna, J. Trzebińsky, J. Mowszowicz have been summarised by Mowszowicz $(1947,1957)$. Because investigations were carried out in the relatively small territory and included mainly common species, this period for mapping purposes was merged with the second stage after the war. The second stage of 1945-1990 can be named the time of focused investigations on the Characeae, initiated by Professor A. Minkevičius (1900-1998). He involved students and 
researchers of different institutions. Main collectors and determinators of the herbarium specimens were A. Minkevičius, I. Trainauskaite, I. Šarkinienè, and the most productive collectors were A. Bagdonaite, J. Pipinys, J. Balevičienė and V. Stepanavičienė.

The third period (1990-2020) represents the increased focus on endangered species, investigations of aquatic flora of protected territories and research related to implementing the Directives of the European Union (Habitat Directive and Water Framework Directive). The primary collection of specimens gathered during this period is concentrated at the Institute of Botany, BILAS. The main determinators of specimens in WI and BILAS herbaria were J. Balevičienè, A. Balevičius, V. Stepanavičienè. Z. Sinkevičienė revised all specimens used in this study.

Table 1. Explanation of symbols used on maps to mark periods of the Characeae species records

\begin{tabular}{|l|c|l|}
\hline Black dot & $\bullet$ & $1990-2020$ \\
\hline Grey dot & $\bullet$ & $1919-2020$ \\
\hline White dot & 0 & $1790-2020$ \\
\hline Black square & $\square$ & $1919-1990$ \\
\hline Grey square & $\square$ & $1790-1990$ \\
\hline White square & $\square$ & $1790-1850$ \\
\hline Question mark & $?$ & doubtful record \\
\hline Cross & + & locality destroyed \\
\hline
\end{tabular}

\section{RESULTS}

The current inventory and revision revealed twenty-one Characeae species, which in Lithuania was confirmed by the herbarium specimens. They are representatives of five genera: Chara (12 species), Nitella (5 species), Tolypella (2 species), Lychnothamnus (1 species) and Nitellopsis (1 species). Thirteen species mentioned in references or on the labels of herbarium specimens were not confirmed occurring in Lithuania.

\section{Distribution maps and comments about confir- med species}

Chara aspera Willd. (Fig. 1)

Chara aspera is distributed in the Northern Hemisphere (Korsch, 2018). The species has been recorded in all European countries (TEPPKE \& BLINDow, 2016), growing in fresh and brackish water. In Lithuania, C. aspera is one of the few species known since the 19th century. WolfGang (1824), among other plants collected by S.B. Gorski, has mentioned C. aspera DC. and C. pusilla Floerke from Lake Akmena. C. pusilla Floerke is a synonym of C. canescens Loisel., but specimens of this name, stored in the WI Herbarium, belong to C. aspera (MinKEvičIUs \& Trainauskaite, 1970). The most comprehensive lists of the Characeae in the 20th century (Š́ 1961; TrainauskaitE, 1970) have indicated this species as quite common, especially in mesotrophic lakes. The occurrence of $C$. aspera was recorded in 64 grid cells and 82 water bodies. The species mainly occurs in permanent lakes and the slightly brackish Curonian Lagoon; it is rarely found in permanent and temporary water bodies, in quarries of clay, sand or gravel. The localities are concentrated in lakes of the Baltic and Samogitian uplands. In Lakes Akmena and Didžiulis, C. aspera has been known since 1823 until now (white dots). In the 20th century and recent decades, the Curonian Lagoon and most of the lakes (especially Lakes Plateliai and Germantas in the western part, Dusia, Meteliai, Vištytis and Žuvintas in the southern part, Lūšiai, Baluošas and Tauragnas in the eastern part) have been investigated several times in different periods, and $C$. aspera has been constantly recorded (grey dots). Studies over the last 30 years have identified many distribution points or confirmed old sites, but there are points (black squares), where the species has not been reinvestigated or was not found (Lake Salotas).

\section{Chara baltica (Hartman) Bruzelius (Fig. 2)}

Chara baltica is a typical species of the Baltic Sea, where its identity has been doubtlessly confirmed (BLÜMEL, 2003). Species are also distributed in the neighbouring areas westward of the Baltic Sea and the Mediterranean Sea (Schubert et al., 2016; Korsch, 2018; Romanov et al., 2019). Romanov et al. (2020) have confirmed the occurrence of C. baltica in the northern part of the Black Sea; however, he has noted that records from Asia, North Africa, South America and Greenland need further confirmation.

Along the Baltic Sea coast in Lithuania, C. baltica has recently been first recorded in the slightly brackish Curonian Lagoon (SINKEVIČIENE, 2004), and 


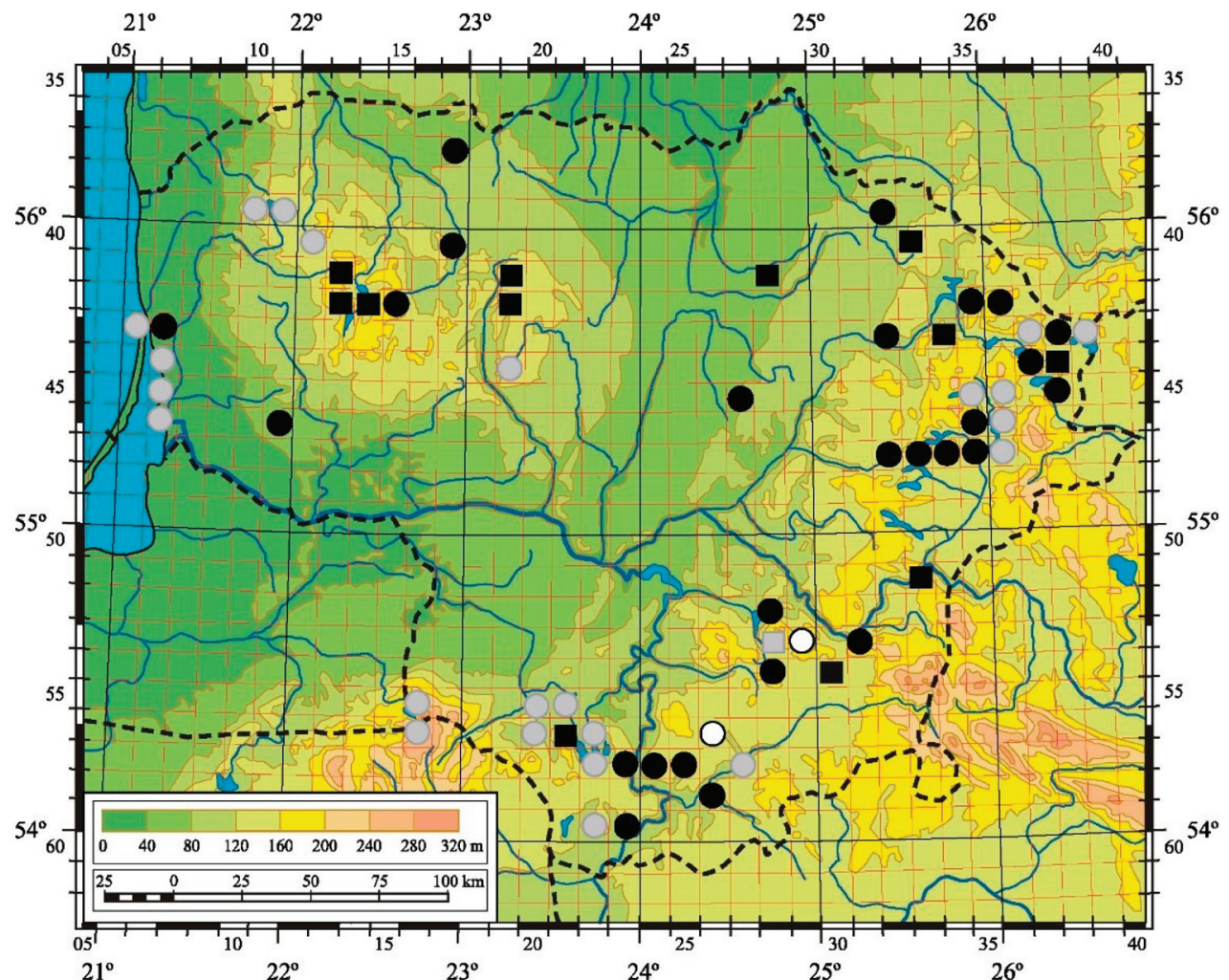

Fig. 1. Distribution of Chara aspera in Lithuania. For the explanation of symbols, see Table 1

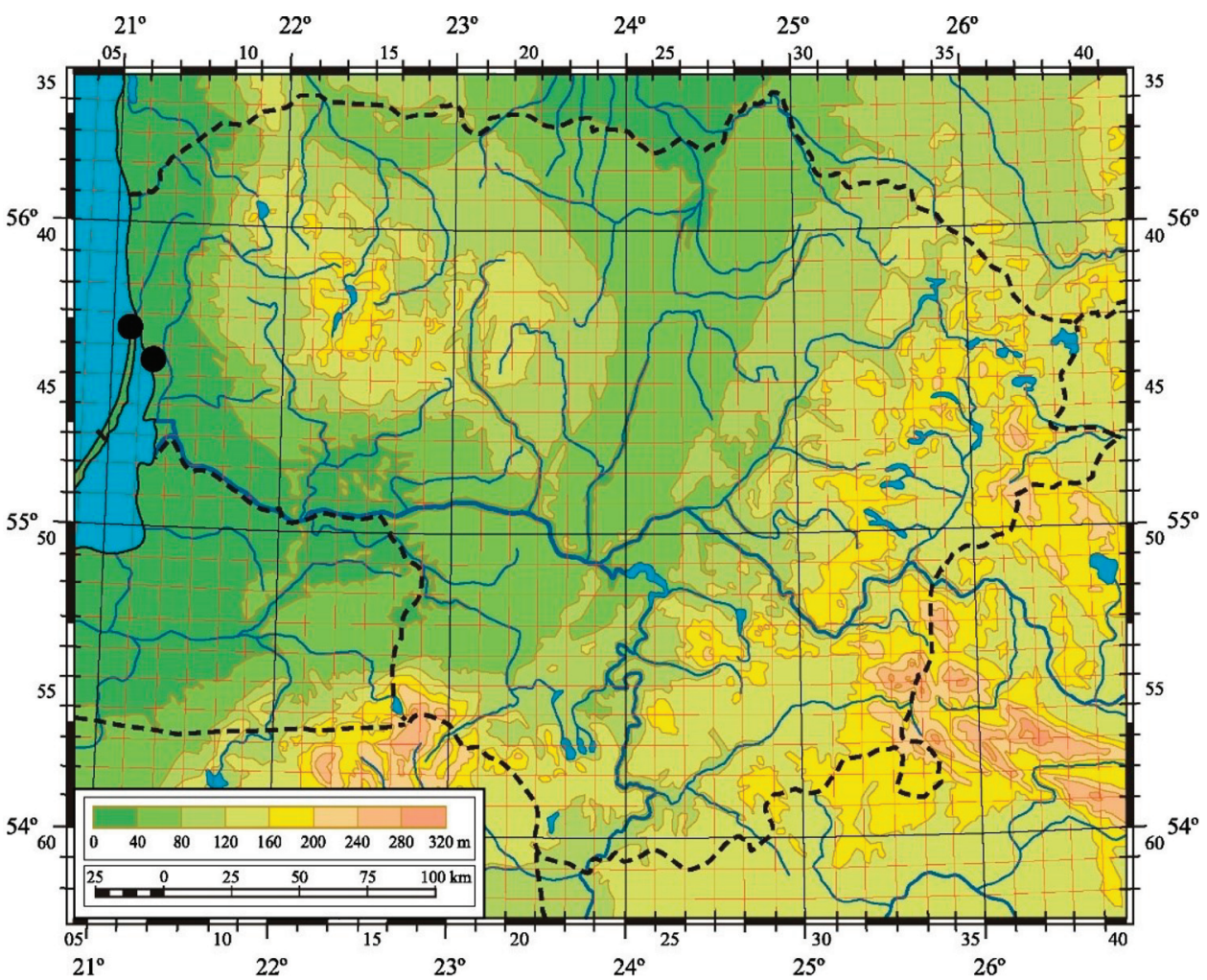

Fig. 2. Distribution of Chara baltica in Lithuania. For the explanation of symbols, see Table 1 
its occurrence was confirmed there in 2014-2015 (SINKEVIČIENĖ et al., 2017). Until now, C. baltica is one of the rarest species in Lithuania. It was recorded only in two grid cells (Fig. 2). Another potential locality for this species along the Baltic Sea coast is near Palanga, where typical brackish water species C. canescens (reported as C. crinita) and Tolypella nidifica were recorded in the 19th century (JunDZIŁE, 1830; RuPRECHT, 1845), have recently changed significantly because of urbanisation. As a result, Chara baltica is included in the Red Data Book and classified as endangered (SINKEVIČIIENĖ, 2007, 2021).

\section{Chara canescens Loisel (Fig. 3)}

Chara canescens is distributed in North America, Europe, Asia, Africa and the south-eastern part of Australia (KoRsch, 2018). In Europe, it is widespread in coastal areas, seacoast influenced by salt waters and inland waters of salt areas (SCHUBERT et al., 2016). Chara canescens is quite common species in the Baltic Sea, where only female plants have been found (Blindow \& SchubERT, 2003). In Lithuania, C. canescens (reported as C. crinita Wallr.) was first recorded in the $19^{\text {th }}$ century at the mouth of the rivers flowing into the Baltic Sea near Palanga (JundziŁt, 1830). However, there are currently no data on C. canescens at the seacoast, and potential sites of its occurrence have significantly changed. This species was recorded in two grid cells in the north-eastern part of the Curonian Lagoon (SinKEVIČIENEE, 2004; SinKEVIČIENĖ et al., 2017). Chara canescens is a rare species and is included in the Red Data Book (SINKEVIČIENĖ, 2007). Recently it has been classified as critically endangered (SINKEVIČIENĖ, 2021).

\section{Chara contraria A. Braun ex Kütz. (Fig. 4)}

Chara contraria is widespread in the Northern Hemisphere, and it was also found in South America, South Africa, and Australia (KoRsch, 2018). It is a freshwater species and only occasionally occurs in brackish water.

In Lithuania, $C$. contraria was not mentioned in the publications at the beginning of the 19th century and even in the accounts by Mowszowicz (1947, 1957). However, its extensive collection from the 19th century is preserved in the WI Herbarium, where the specimens are named "Chara Gorskiego" or only marked with numbers (MinkEvičIUs \&
TrainausKaité, 1970). Localities mentioned on the labels now are situated directly in Vilnius city or close proximities (white dots, grey square). Since the mid- $20^{\text {th }}$ century, $C$. contraria has been considered one of the widespread species in lakes and other water bodies (Š́ARKINIENĖ, 1961; TRAINAUSKaité, 1970; Šarkinienè \& Trainauskaité, 1973). According to obtained data, C. contraria was confirmed in 96 grid cells and 112 water bodies. The species distribution is mainly related to the Lakelands of uplands, where the species continually occurs in many cases since the middle of the last century (grey dots). Scattered throughout the territory, the localities show its occurrence in different water bodies such as temporary and permanent waters in quarries of sand, gravel, clay or lime, in ponds of towns or settlements, ditches, riverbeds and depressions in the wetlands. Chara contraria is the most common species in the slightly brackish Curonian Lagoon (MinkevičIus \& PiPInYs, 1959; SINKEVIČIENE et al., 2017). The species is abundant in Lakes Alnis, Dusia, Didžiulis (Daugai), Germantas and Vištytis.

Chara filiformis A. Braun in Hertzsch (Fig. 5)

Chara filiformis has limited European distribution (Korsch, 2018). This species has been recorded in Belarus, Denmark, France (Pyrenees), Russia, southern Sweden (Corillion, 1957) and Switzerland, but it is most widespread in Germany, Poland, Lithuania and Latvia (SINKEVIČIENÉ, 2019).

In Lithuania, C. filiformis was first mentioned in the early 19th century as $C$. funicularis Pers. (WolfGANG, 1822; GorsKI, 1830). At that time, the species had been collected in several lakes close to Vilnius city, where it has occurred until now (white dots). The species was named C. tyzenhausii by GorsKI (1849). This name was not validly published, but used by Mowszowicz (1947), Minkevičius \& Trainauskaitė (1957), Mardosaité \& Minkevičius (1958). In the accounts of the Characeae by ŠARKINIENE (1961) and TrainausKaité (1970), this species was listed as Chara jubata A. Braun. At that time, the species had been considered quite widely distributed in the lakes throughout the country. Chara filiformis was recorded in 58 grid cells and 95 lakes. The localities were concentrated in the southern and eastern parts of the country. In most of the localities, the species was found repeatedly (grey dots). In Lithuania, 


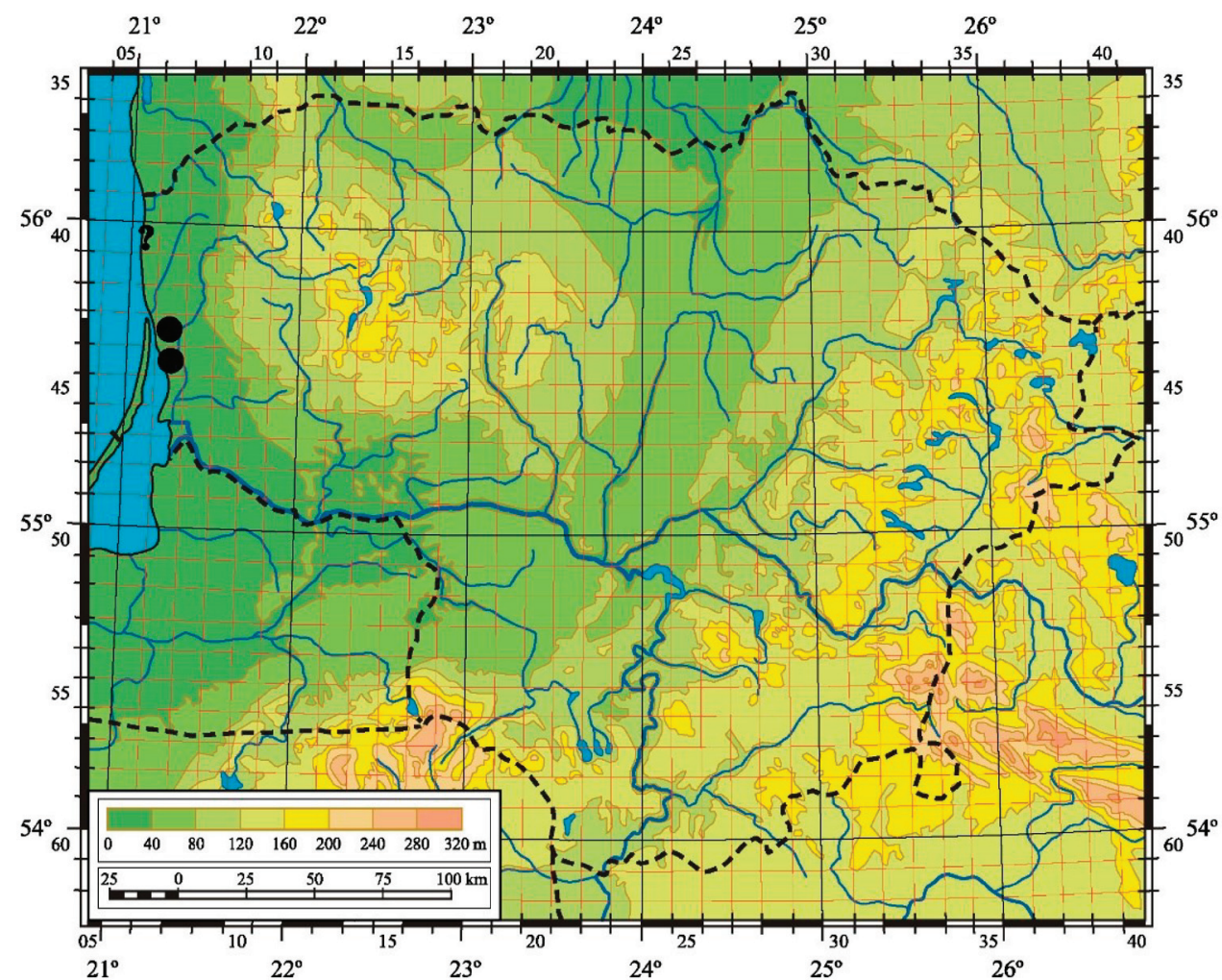

Fig. 3. Distribution of Chara canescens in Lithuania. For the explanation of symbols, see Table 1

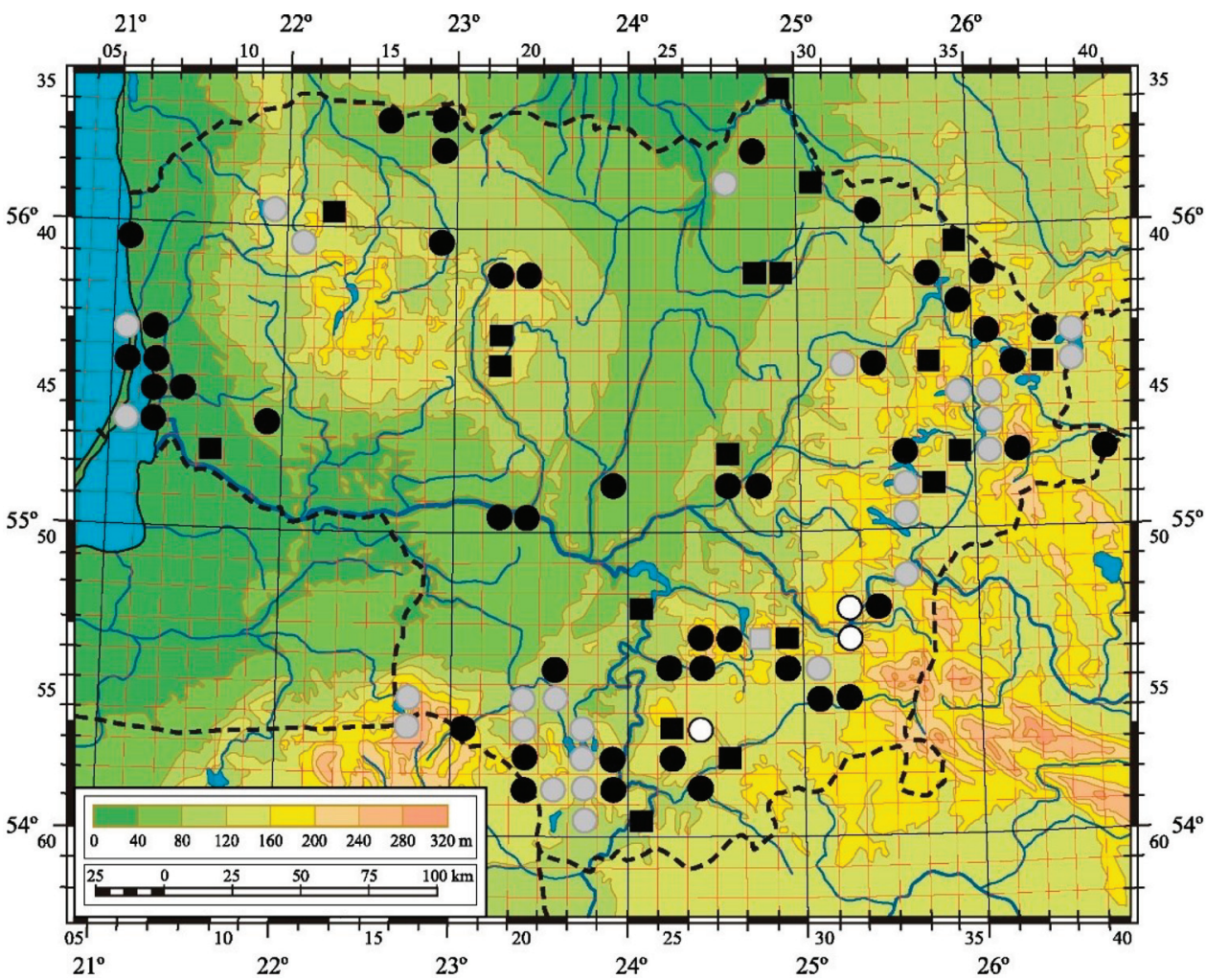

Fig. 4. Distribution of Chara contraria in Lithuania. For the explanation of symbols, see Table 1 
C. filiformis grows in the lakes and has never been recorded in other types of water bodies.

\section{Chara globularis Thuill. (Fig. 6)}

Chara globularis is a cosmopolitan species recorded in all continents, but most widely distributed in the Northern Hemisphere (KorsCH, 2018).

In Lithuania, $C$. globularis was first mentioned as Chara pulchella Wallr. (WolfGANG, 1824; GoRSKI, 1830). Abundant herbarium material was collected in the vicinities of Vilnius city (MinKEvičIUs $\&$ Trainauskaite, 1970), where the species occurred at that time and still occurs today (white squares and white dots, respectively). C. globularis was recorded in 150 grid cells and 260 water bodies, and it is the most common species. Despite the apparent concentration of localities in Lakelands, the distribution throughout the country is much more even than that of other species. In addition to lakes, this species was found in a wide range of water bodies: water reservoirs, waters of various quarries, in springs, wetland pits, ditches, rivers of different sizes and in river oxbow lakes. Since the middle of the 20th century, the most permanent occurrence has been noticed in lakes, which had been reinvestigated several times (grey dots). Points outside of main Lakelands situated in lowland agricultural areas mainly are not reinvestigated (black squares). Abundant new localities (black dots) include different types of water bodies.

\section{Chara papillosa Kütz. (Fig. 7)}

According to Korsch (2018), C. papillosa is distributed in North America and Europe. However, the global distribution of the species is unclear because of difficult delimitation from related taxa belonging to the group of C. hispida (SCHUBERT et al., 2016).

In Lithuania, C. papillosa, as C. intermedia A. Braun, has been first reported by Mowszowicz (1947) from the surroundings of Vilnius. However, in the WI Herbarium collection of the 19th century, specimens of this species were identified by MinKEVIČIUS \& Trainauskaité (1970) as C. aculeolata Kütz. (C. intermedia A.Br.). This name was also used by other researchers (TRAINAUSKaITĖ, 1970; ŠARKINIENĖ $\&$ Trainauskaite, 1973). In the mid-20th century, it was considered a rare species, mainly occurring in small water bodies. A part of the herbarium specimens (WI, BILAS), collected from 1945 to 1990, was identified as C. hispida. According to all available data, C. papillosa was recorded in 46 grid cells and 48 water bodies. The distribution sites are scattered throughout the country, because the species is not limited to the large lakes and more often occurs in small ones or other small water bodies: temporary or permanent waters in clay, gravel, sand quarries, in wetland depressions and ditches. These latter types of water bodies are poorly studied, so the species may be more widespread.

\section{Chara strigosa A. Braun (Fig. 8)}

Chara strigosa is distributed in Europe, Asia, and the north-western part of Africa (KoRsch, 2018;). In Europe, its distribution is concentrated in the alpine region and northern Scandinavia, but also it is recorded in the Baltic States, Russia and the Balkans (Vishnyakov et al., 2021; Jorda \& BeCKer, 2016).

In Lithuania, the first herbarium specimens of C. strigosa were collected in 1953; however, this species for a long time had been misidentified as C. polyacantha (ŠARKINIENE 1961, 1968; Trainauskaité, 1970; Šarkinienè \& Trainauskaité, 1973; SinkeviČIENĖ, 1994). Chara strigosa was referred after the specimen revision in the WI and BILAS Herbaria (SINKEVIČIENĖ, 2007; KosTKEVIČIENE \& SinKEVIČIENĖ, 2008). C. strigosa was recorded in 39 grid cells. Species occurs only in lakes and, so far, has been found in 52 lakes. Most abundant populations recently have been revealed in Lakes Sągardas, Kliokis and Viešintas. Although this species is not protected in Lithuania, its populations should be permanently surveyed, as C. strigosa is threatened in many European countries (JORDA \& BECKER, 2016).

\section{Chara subspinosa Rupr. (Fig. 9)}

Chara subspinosa is distributed in Europe and Asia (KoRsch, 2018). It is widespread in many European countries, but it is more frequent in the northern part of the range, and in Asia, it extends beyond the Ural Mountains through Siberia to the Altai Mountain (SCHUBert et al., 2016).

In Lithuania, even though many old literature sources mention the occurrence of C. hispida (JunDZiŁe, 1791; WolfGANG, 1822; JunDZIŁE, 1830), specimens of $C$. subspinosa were found only in the collection of the 19th century (MinkevičIUs \& Trainauskaite, 1970). Chara hispida f. brachyteles 


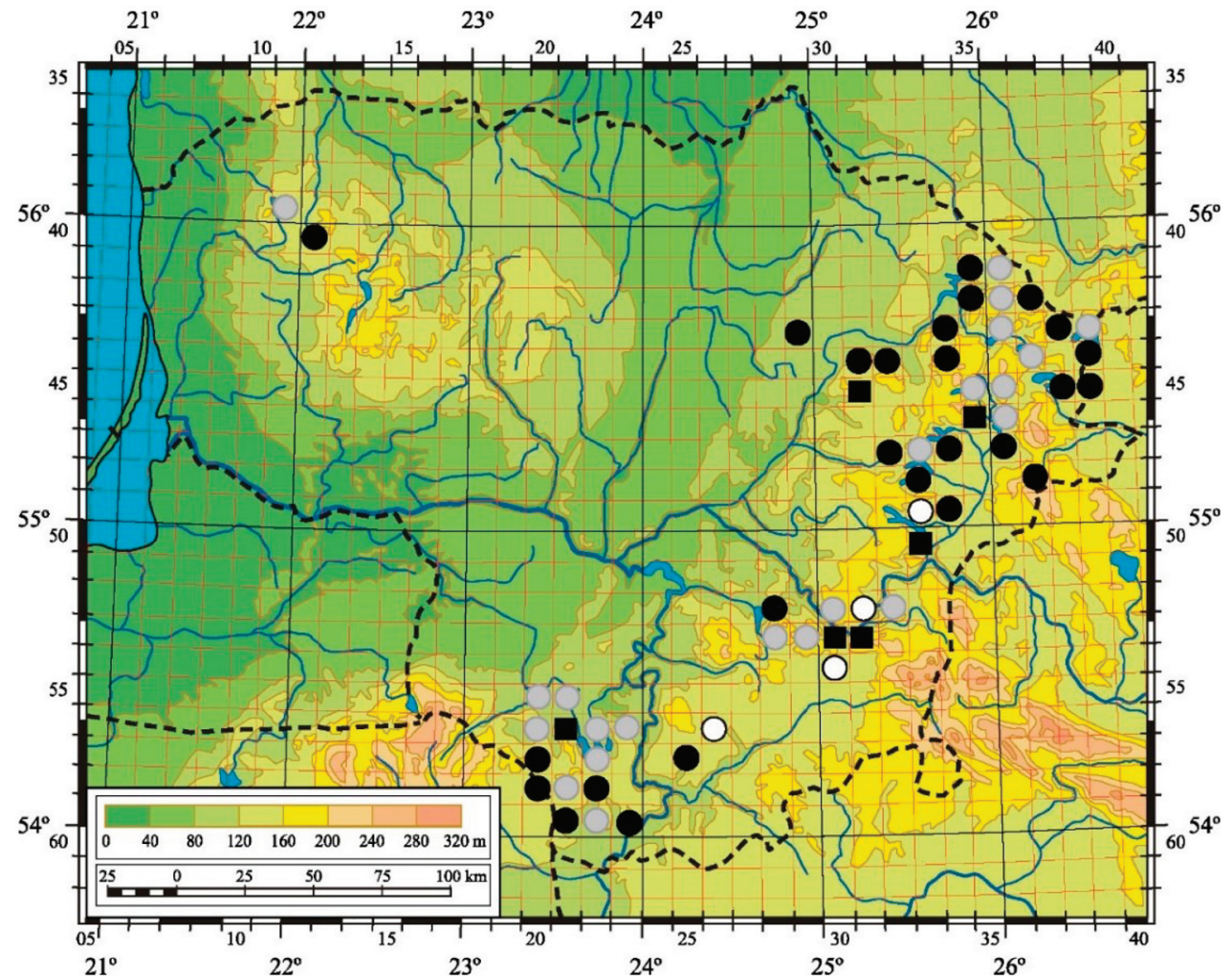

Fig. 5. Distribution of Chara filiformis in Lithuania. For the explanation of symbols, see Table 1

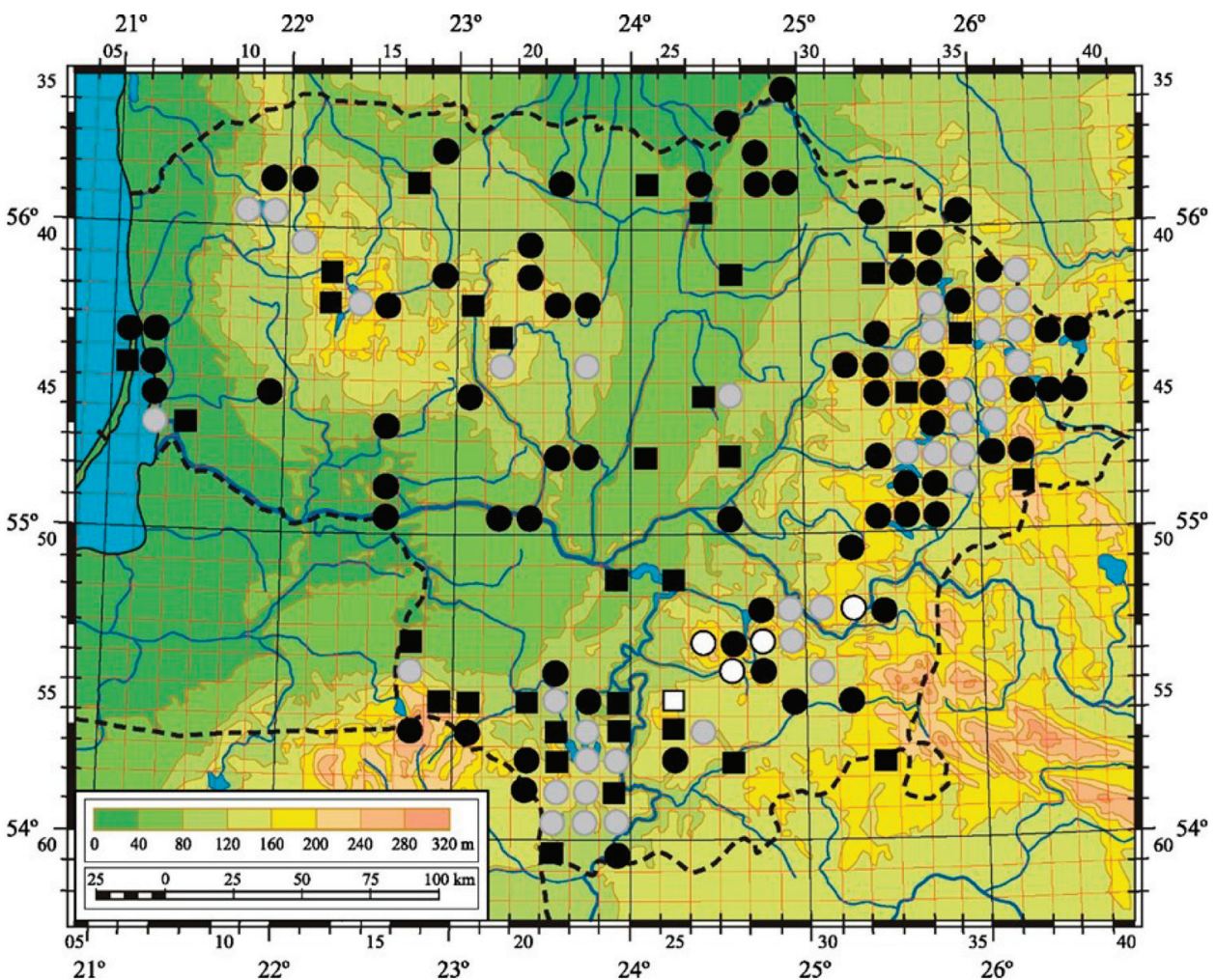

Fig. 6. Distribution of Chara globularis in Lithuania. For the explanation of symbols, see Table 1 


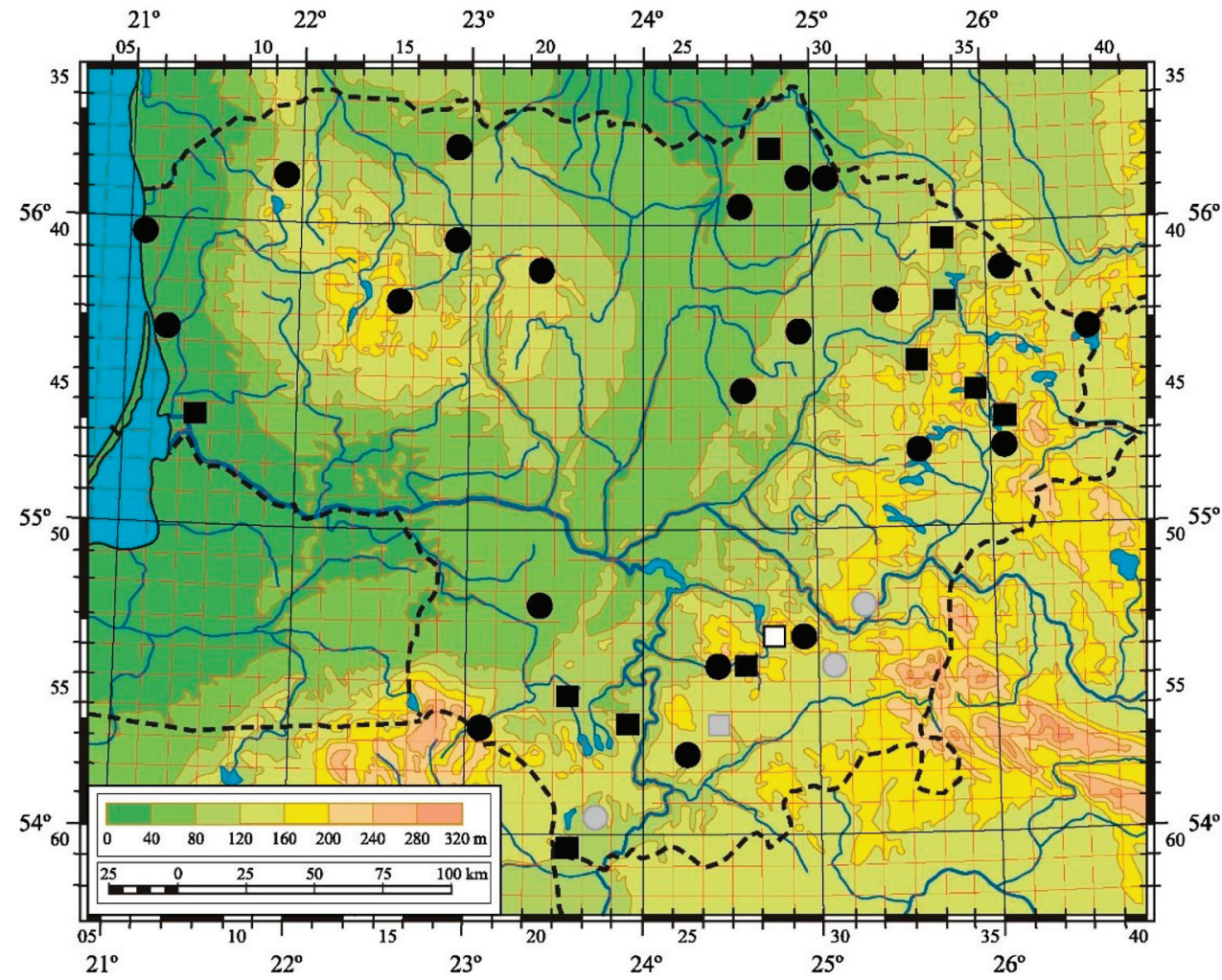

Fig. 7. Distribution of Chara papillosa in Lithuania. For the explanation of symbols, see Table 1

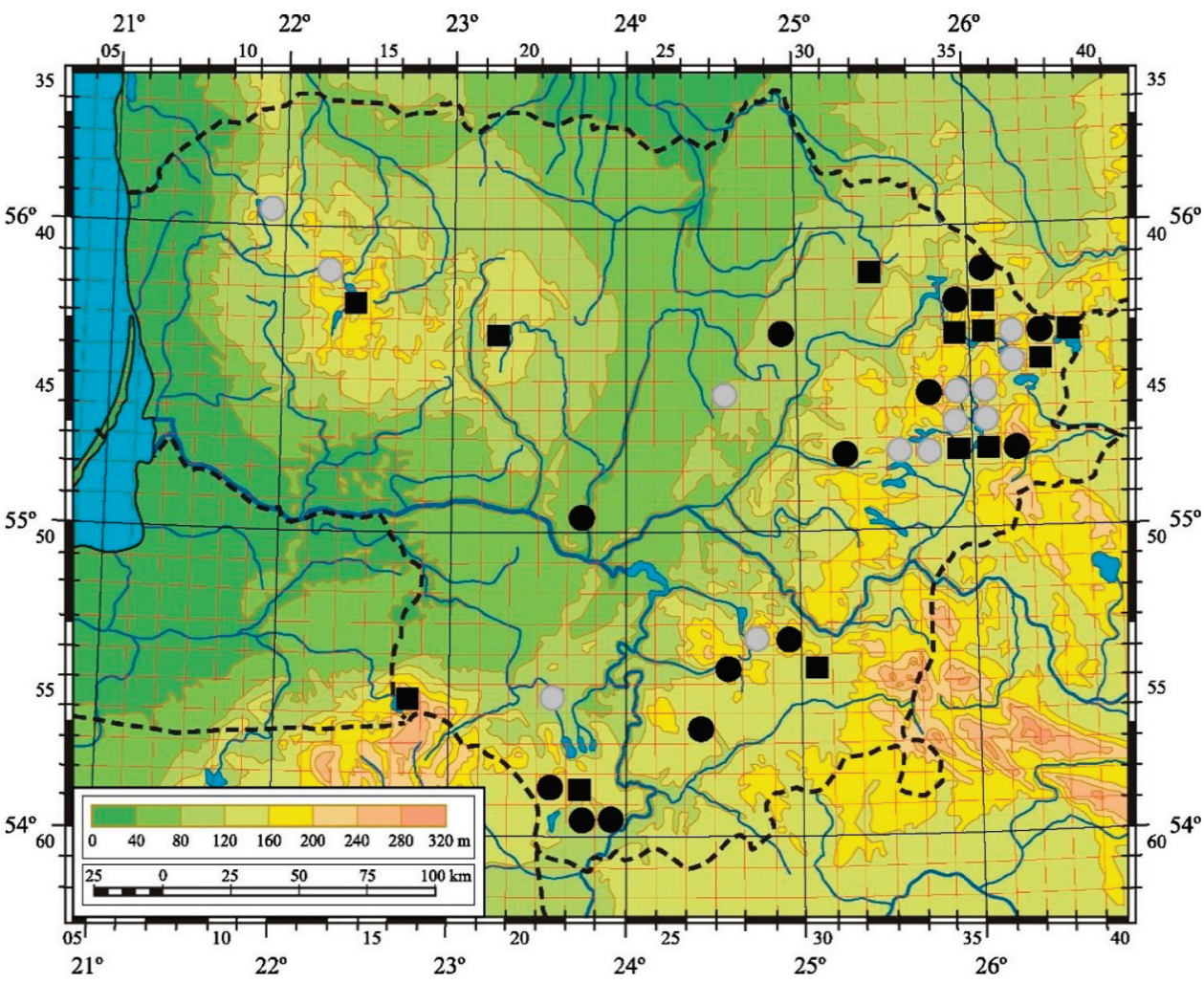

Fig. 8. Distribution of Chara strigosa in Lithuania. For the explanation of symbols, see Table 1 


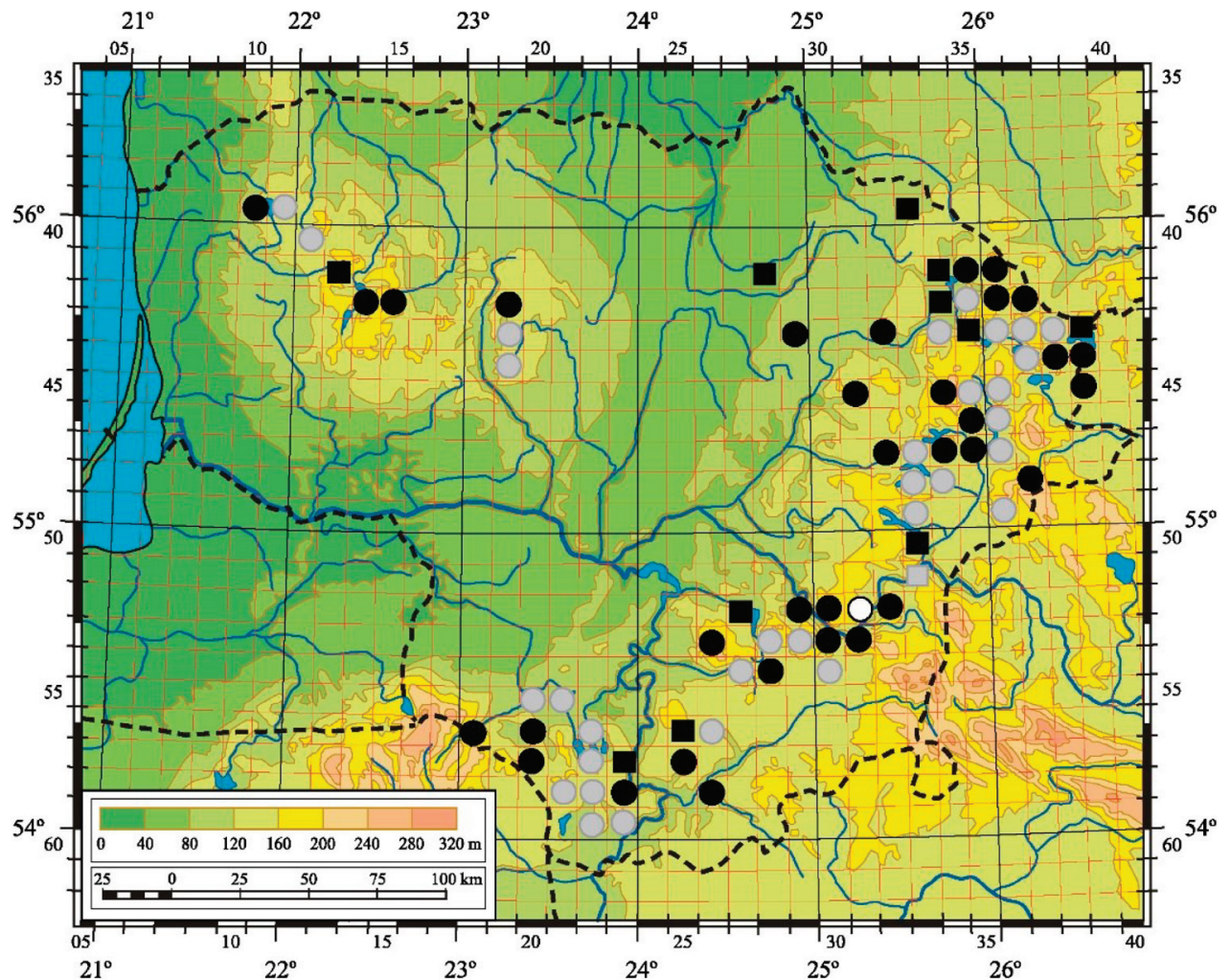

Fig. 9. Distribution of Chara subspinosa in Lithuania. For the explanation of symbols, see Table 1

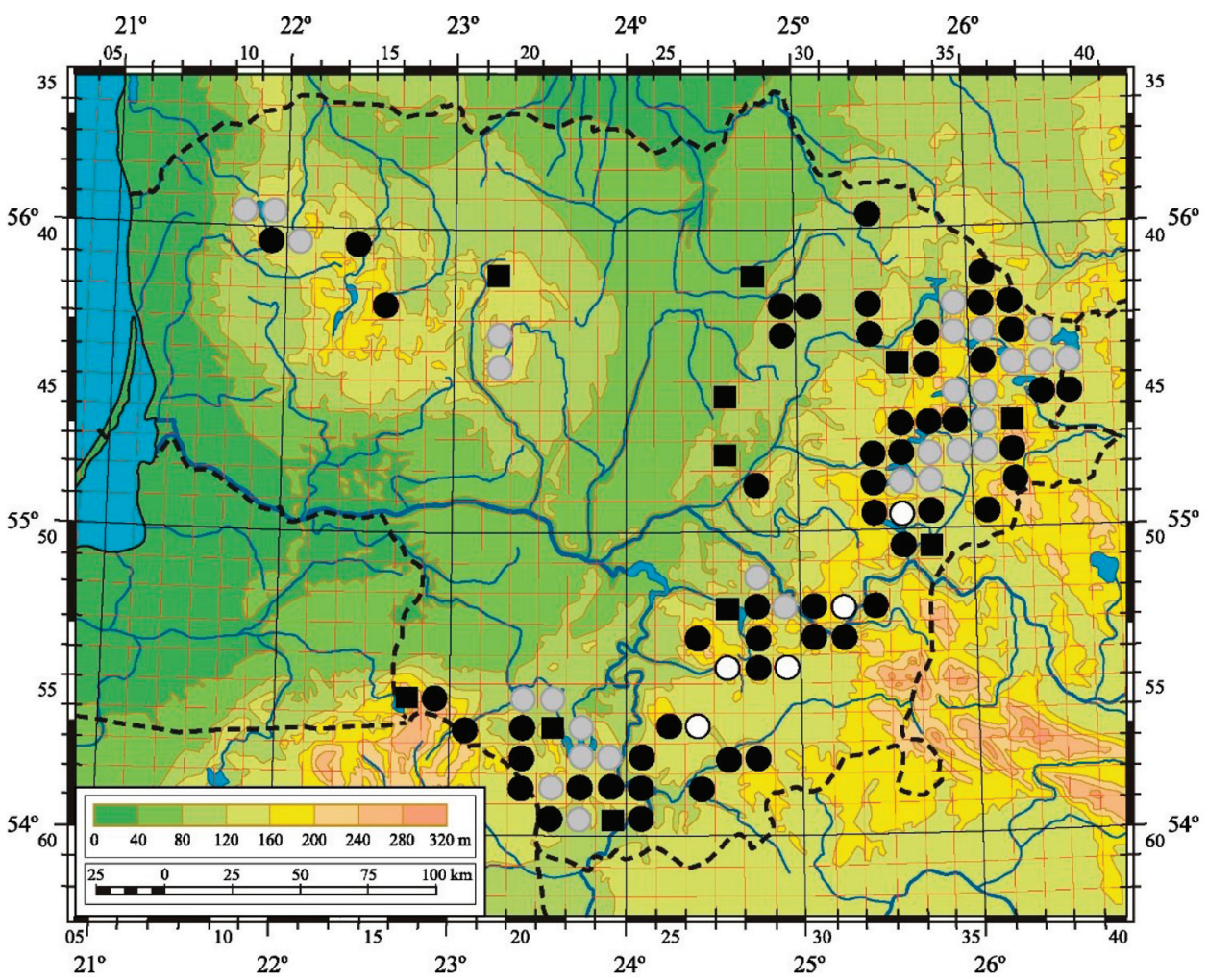

Fig. 10. Distribution of Chara tomentosa in Lithuania. For the explanation of symbols, see Table 1 
in the picture drawn by GoRski (1849, Table XVI) resembles C. subspinosa (C. rudis) (Galinis, 1968). On labels of the herbarium specimens and in references, this species for a long time had been named as C. rudis A. Braun (Mowszowicz, 1947; ŠArkiniené, 1961; Trainauskaité, 1970; ŠarkinienĖ \& Trainauskaité, 1973; KostKevičIEnĖ \& SinkevičIEnĖ, 2008). Since the mid-20th century, it has been considered one of the most common species (TrainaUSKAITE 1970). Until now, C. subspinosa has been recorded in 111 lakes, where it usually occupies large areas of the bottom and is never found in other types of water bodies. Its occurrence was confirmed in 79 grid cells mainly related to Lakelands, especially on Aukštaitija, Dzūkija and Sūduva uplands.

\section{Chara tomentosa L. (Fig. 10)}

Corillion (1957) has treated C. tomentosa as a cosmopolitan species; however, KorsCH (2018) has shown that its distribution is restricted to Europe, North Africa and Asia. It is a freshwater species, but in the Baltic Sea occurs in brackish water (ToRN et al., 2003).

In Lithuania, C. tomentosa is one of the most common species, first mentioned in the late 18th century (JunDZIŁE, 1791), and later for a long time had been named C. ceratophylla Wallr. (GorsKI, 1830; Mowszowicz, 1947; Minkevičius \& Trainauskaité, 1957; ŚARKINIENE, 1961). From the beginning of the 19th century until now, $C$. tomentosa had been known from a few locations near Vilnius (white dots). Since the mid-20th century, the distribution of the species has been confirmed throughout the country and in many locations it is still found until now (grey dots). C. tomentosa was recorded in 97 grid cells and 187 water bodies. It occurs in freshwater only, usually in lakes and water reservoirs created after the damning of rivers flowing through the lake systems.

\section{Chara virgata Kütz. (Fig. 11)}

Chara virgata is an almost cosmopolitan species distributed in North America, Europe, Asia and a small part of Africa and Australia (Korsch, 2018). In Europe, it is widespread almost in all countries (Doege \& van De Weyer, 2016). Chara virgata is a freshwater species, only occasionally found in brackish water.

In Lithuania, $C$. virgata was first reported by Mowszowicz (1947) only in the 20th century as C. del- icatula C. Agardh. However, we found a specimen of this species in the WI Herbarium, collected in the 19th century, among samples of C. globularis. Chara virgata, for a long time, had been considered quite a rare species (ŠARKINIENĖ, 1961; TRAINAUSKAITÉ, 1970). Part of the specimens in the herbaria were misidentified as C. globularis; furthermore, transitional forms exist between both species. The occurrence of $C$. virgata was recorded in 66 grid cells and 93 water bodies. Localities are mainly concentrated in Aukštaitija, Sūduva and Samogitia uplands and related with main Lakelands. Chara virgata is primarily found in lakes of different sizes, but its groves rarely occupy large areas. It also occurs in waters of limestone, clay, sand or gravel quarries, rivers, ditches, and pools of different wetlands. Although C. virgata often co-occurs with $C$. globularis; however, it is not as widespread and is found in fewer water bodies.

\section{Chara vulgaris L. (Fig. 12)}

Chara vulgaris is a cosmopolitan species common on all continents (KoRSCH, 2018). It is a freshwater alga, but is also found in slightly brackish water (TORN \& MARTIN, 2003).

In Lithuania, $C$. vulgaris is one of the few species mentioned since the late 18th century (JunDzIŁL, 1791) and listed in the main account by GoRSKI (1830). In the first half of the 20th century, the synonym $C$. foet$i d a$ was applied for this species (Mowszowicz, 1947; ŠARKINIENE, 1961), and its form was considered a separate species $C$. crassicaulis Schleich. TRAINAUSKaITĖ (1970) has assessed this species as widespread; however, former and recent herbarium material is relatively poor. According to the available data, C. vulgaris was recorded in 58 grid cells and 94 water bodies. The distribution map revealed a completely different distribution pattern than many other Chara species, because $C$. vulgaris is typical of small water bodies and is rarely found in lakes. Its habitats are often in wetlands around the lakes and along the rivers, riverbeds, drainage ditches, ponds, springs, spring fens, etc. Because small water bodies are quite poorly investigated, this species may be more widespread.

\section{Lychnothamnus barbatus (Meyen) Leonh.} (Fig. 13)

Lychnothamnus barbatus has a disjunctive distribution range with localities in Europe, Asia, Aus- 


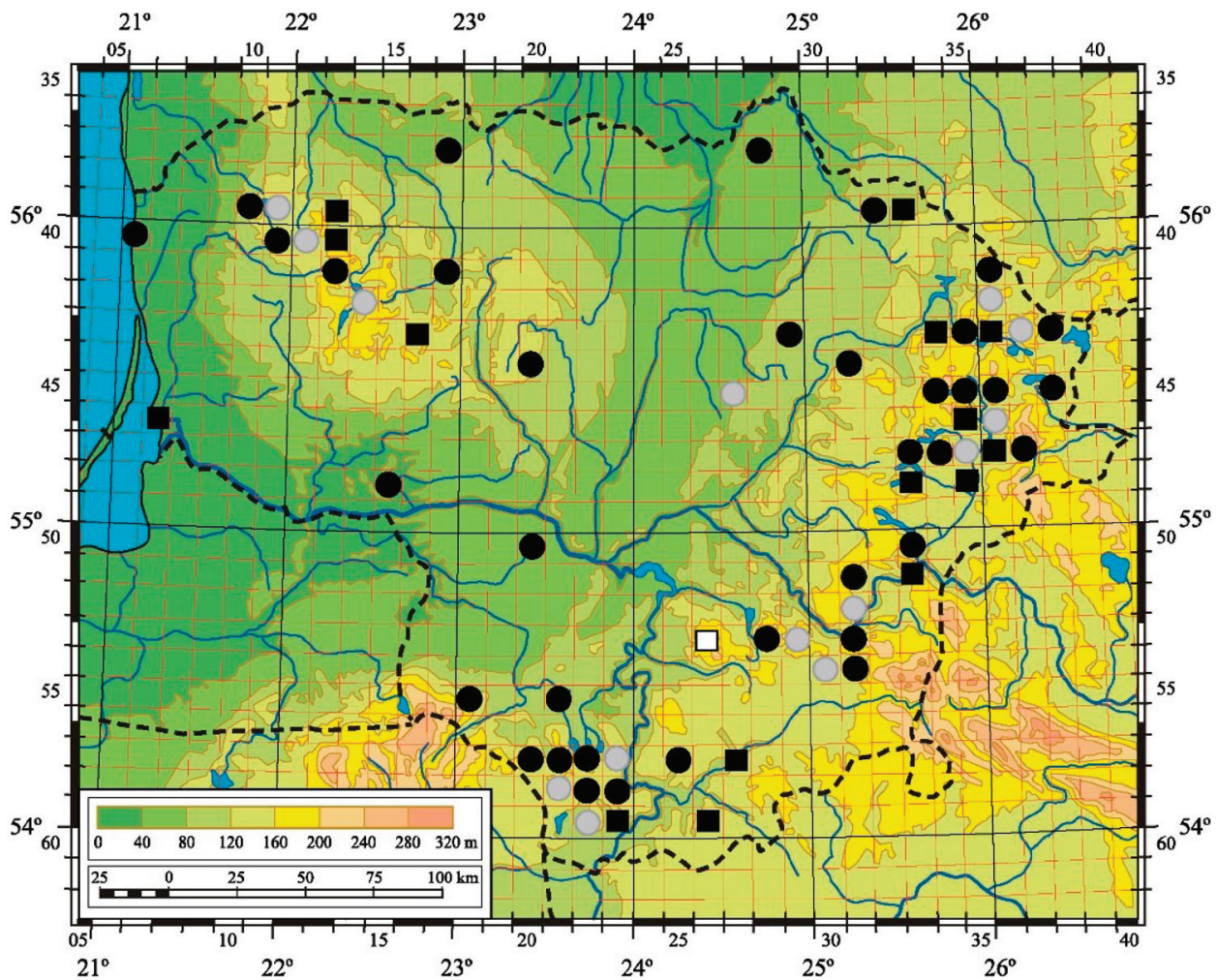

Fig. 11. Distribution of Chara virgata in Lithuania. For the explanation of symbols, see Table 1

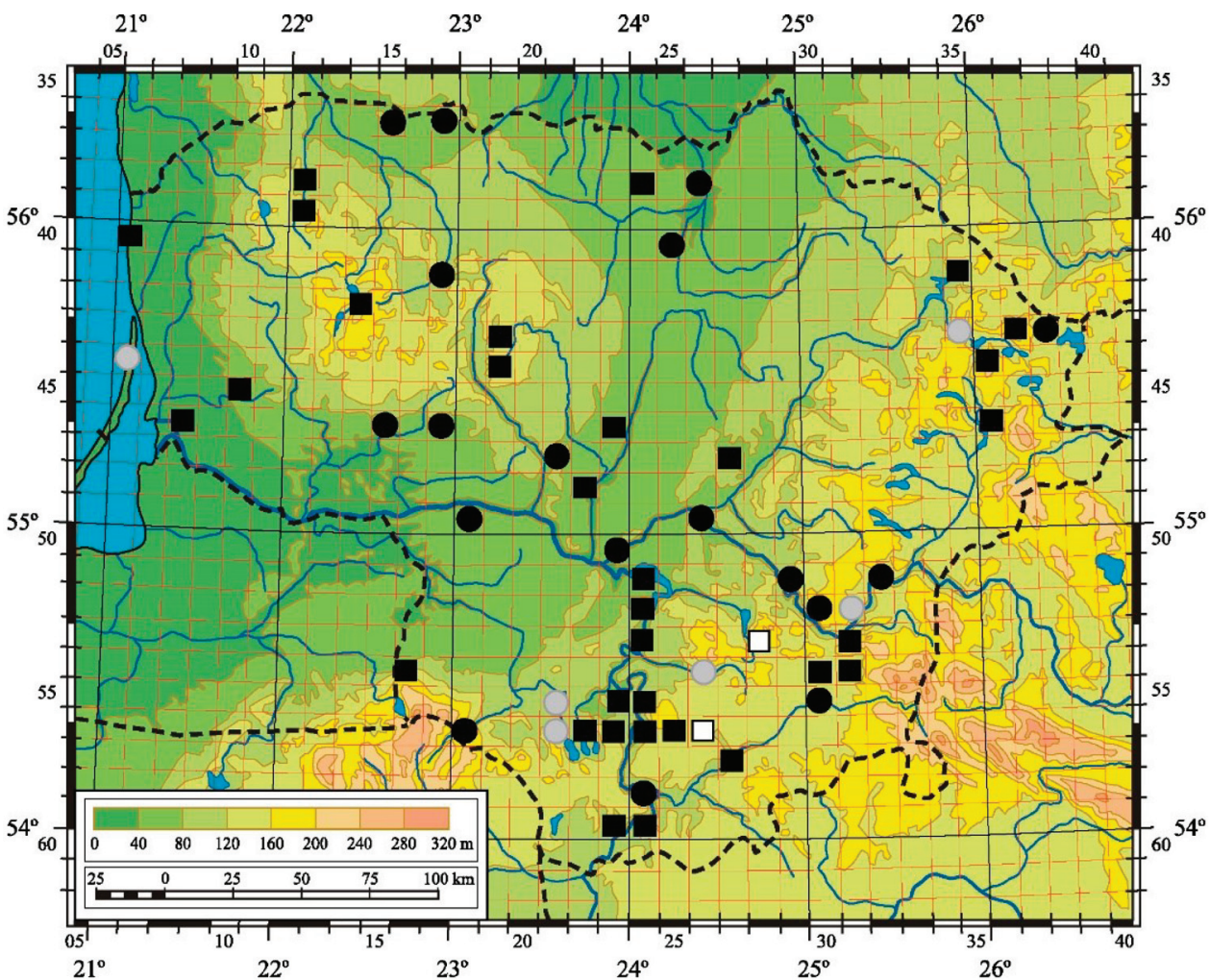

Fig. 12. Distribution of Chara vulgaris in Lithuania. For the explanation of symbols, see Table 1 
tralia, and North America (Korsch, 2018; Romanov, 2019). SugIER et al. (2010) have listed 12 countries in Europe, where L. barbatus occurrence is recorded. The latest additional record is from Portugal (RoMANOV, 2019). Despite the wide range of the species, stable populations are known only in several water bodies in Poland, Lithuania and Croatia (SugIER et al., 2010).

In Lithuania, L. barbatus is one of the few species known since the 19th century. WoLfGANG (1824) has reported about new Chara species in Lake Šventininkai. Abundant herbarium specimens gathered in this lake by S.B. Gorski were named Chara radiata 'mihi'. By mistake GoRsKI (1830) himself reported $C$. brachiata Dierb. instead of $C$. radiata. Lake Šventininkai most probably is the first locality in Europe, where species later validly described as Chara barbata by Meyen (1827) and assigned to the genus Lychnothamnus by LEONHARDI (1863) has been found. In Lake Šventininkai, L. barbatus occurs until now (white dot), when the species has recovered after severe pollution of the lake by wastewater (SinKEVIČIENĖ \& URBAITĖ-MAŽEVIČ, 2012). In addition, in the middle of the 20th century, this species was recorded in Lakes Balsys, Gulbinas, Mažasis Gulbinas, Vygris, Sągardas (ŠSARKINIENĖ, 1961; GALINIS, 1963; BALEVIČIUS, 2001). The latest records have been made in Lakes Viesai and Liškiavis. One location in Lake Sągardas is still questionable, because no herbarium specimens confirming L. barbatus occurrence were found, and the species has not been recorded during focused searches. Lychnothamnus barbatus has been included in the Red Data Book of Lithuania since 1992 (Trainauskaité, 1992; SinkeVIČIENÉ, 2007). Recently, this species has occurred in six lakes and has been treated as endangered (SINKEVIČIENĖ, 2021).

Nitella confervacea (Breb.) A. Braun ex Leonh. (Fig. 14)

Nitella confervacea is distributed in North America, North and South Africa, Europe and Southeast Asia (Korsch, 2018). This annual species is rare in large parts of Europe, but could be easily overlooked (PÄtzolt et al., 2016), having its small size in mind. Nitella confervacea is found from fresh to brackish waters in different types of water bodies, usually in shallows (Pätzolt et al., 2016; Guiry \& Guiry, 2021). The studies in Germany revealed the distribu- tion of $N$. confervacea in water bodies of deep quarries in depth up to $8 \mathrm{~m}$ (PÄtzolt et al., 2016).

In Lithuania, $N$. confervacea has been known since the beginning of the 19th century. It was first recorded as Chara batrachosperma Pers. (WolfGANG, 1824; GoRSKI, 1830). Herbarium specimens indicated two sites (the River Varenè at Junčionys and a ditch in a wet meadow near Alsakiai), but was never found there again (white squares). Locality recorded by Mowszowicz (1947) in Vilnius city is obviously destroyed. Currently, $N$. confervacea is known from one locality at the shore of Lake Žuvintas. After this finding in 2004, the species was red-listed (SINKEVIČIENĖ, 2007) and is currently treated as critically endangered (SINKEVIČIENĖ, 2021). Although after the extensive drainage and land reclamation in the 20th century, habitats suitable for $N$. confervacea have been significantly reduced, the species may be more widespread than recorded here, because it has been overlooked due to its small size.

\section{Nitella flexilis (L.) C. Agardh (Fig. 15)}

Nitella flexilis is a cosmopolitan species widespread in North and South America, Europe and Asia, but scattered in Africa and Australia (Konsch, 2018). In Europe, it is much more frequent in the western and central parts than in the southern part of the continent (BECKER \& WolfF, 2016).

In Lithuania, the characterisation of $N$. flexilis distribution is complicated because of its difficult separation from the morphologically similar $N$. opaca. First references of the early 19th century reported only $N$. flexilis, and it was named Chara flexilis L. (WolfGANG, 1824; Gorski, 1830). Although N. opaca or both species have been mentioned in the literature since the middle of the 20th century (MinKEVIČIUS, 1954; MinkeviČIus \& Trainauskaité, 1957; ŠArkinienĖ, 1961; Trainauskaité, 1970), available herbarium material mainly consists of sterile plants or, rarely, of clearly monoecious plants or individuals with mature oospores. We cannot affirm that $N$. opaca does not occur in Lithuania, but so far, no herbarium specimens are confirming its occurrence. The compiled map includes localities of fertile and sterile plant specimens; thus, it may contain several localities of $N$. opaca. In any case, $N$. flexilis appears to be more common than it was earlier supposed. The map of distribution shows a pattern typical for lake 


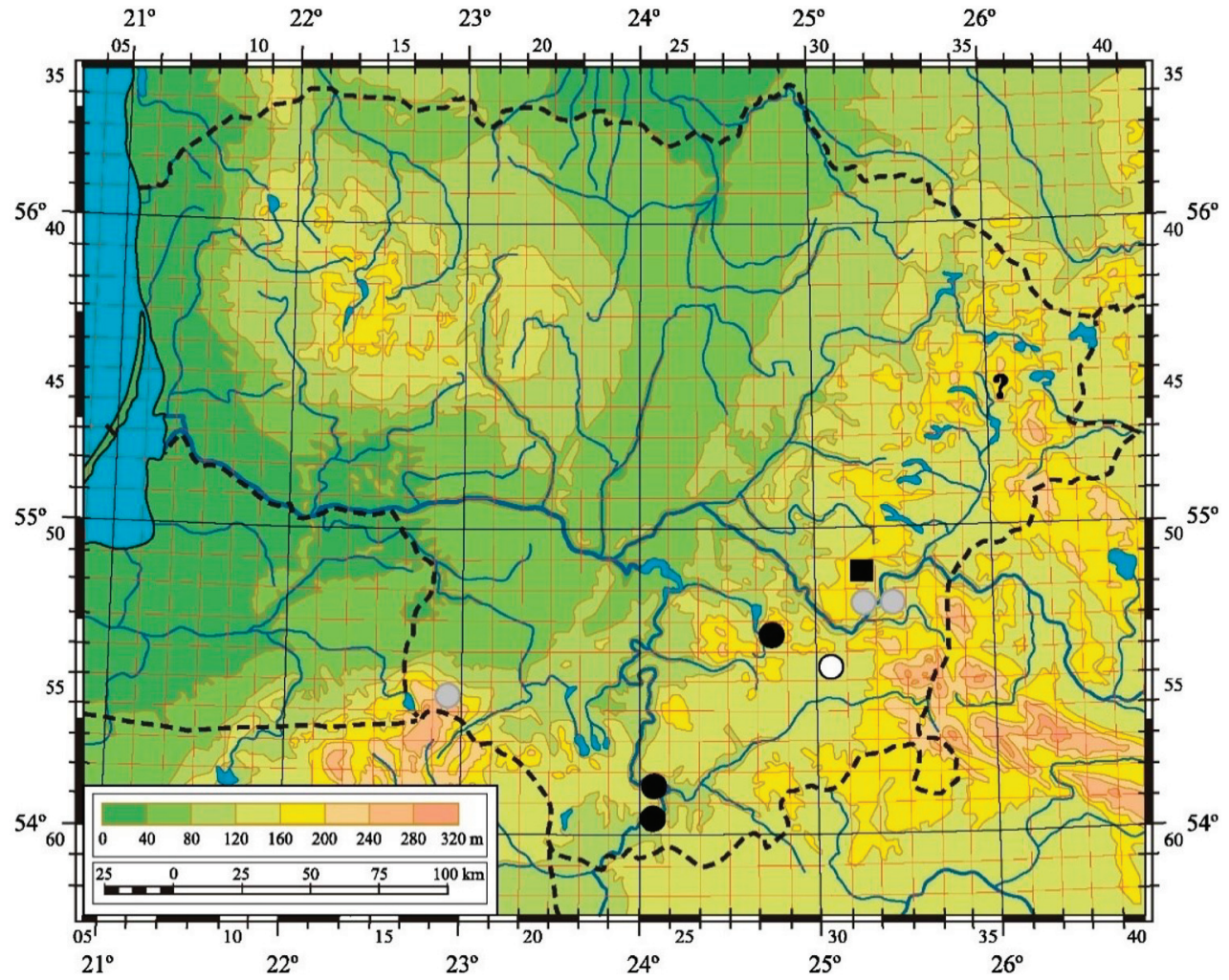

Fig. 13. Distribution of Lychnothamnus barbatus in Lithuania. For the explanation of symbols, see Table 1

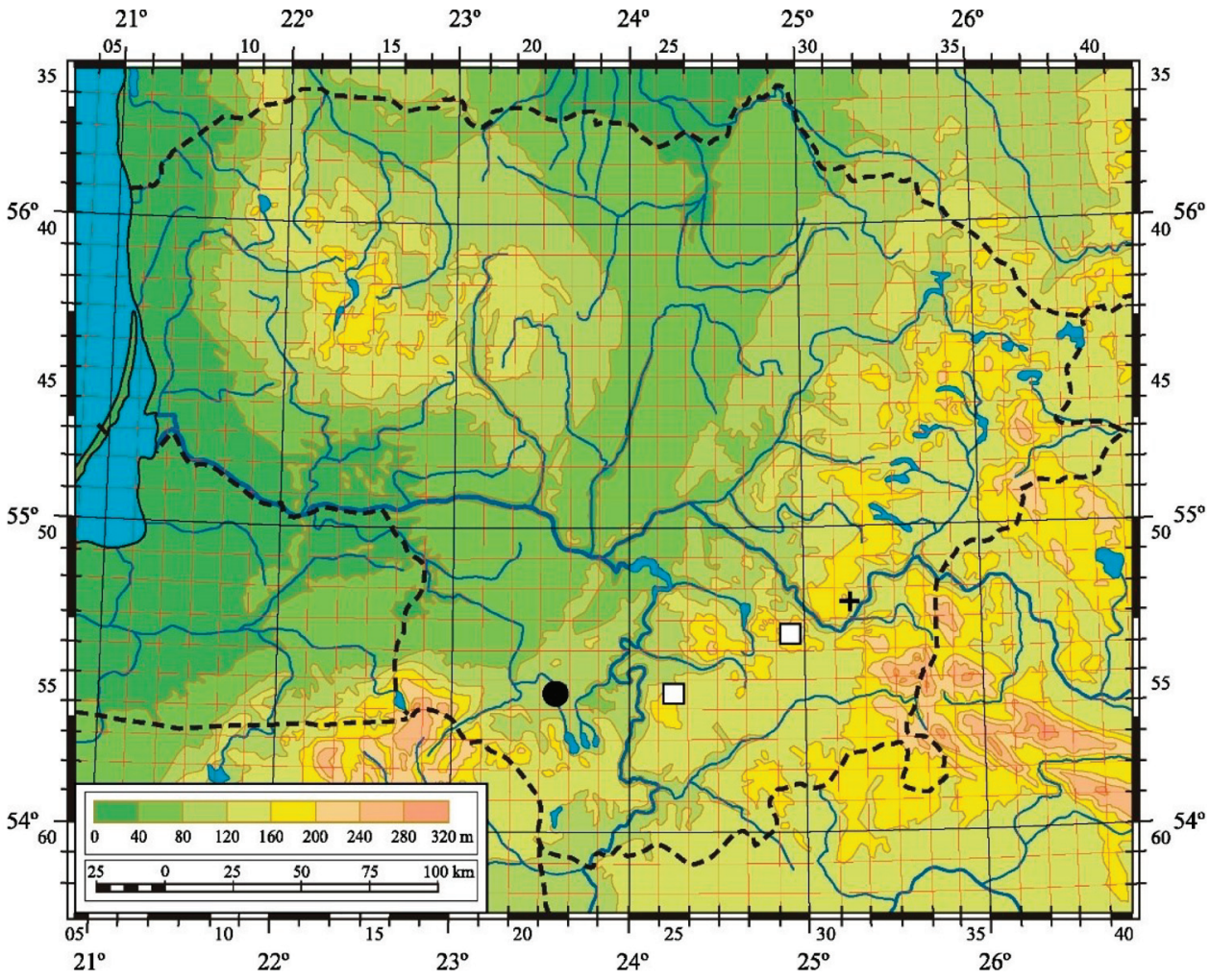

Fig. 14. Distribution of Nitella confervacea in Lithuania. For the explanation of symbols, see Table 1 
species. Only rarely $N$. flexilis was recorded in artificial ponds, rivers or ditches. It is a common species altogether recorded in more than a hundred lakes distributed in 72 grid cells.

Nitella gracilis (J.E. Smith) C.A. Agardh (Fig. 16)

Nitella gracilis is widespread in Eurasia, occurs in North and South America; scattered locations are in Africa and Oceania (Korsch, 2016). In Europe, $N$. gracilis is recorded in many countries, but most is scarce and threatened (KORSCH, 2016; BECKER, 2016).

In Lithuania, the presence of $N$. gracilis has been unclear for a long time. It was first mentioned by WolfGang (1822) as Chara gracilis; however, GoRSKI (1830) did not include this species in his account. Mowszowicz (1947) reported about specimens of $N$. gracilis stored in the collection by Gorski of the 19th century. However, MinkEvičIIUS \& TRAINAUSKAITE (1970), after the revision of this herbarium, did not mention this species. We found several specimens named $C$. gracilis, collected in 1823 , though they belong to other Nitella species. TrainausKaité (1970) has reported two locations of $N$. gracilis in Lake Žiedelis (western Lithuania) and a ditch in the southern part of the country, however, without supporting herbarium material. Nitella mucronata was collected only in Lake Žiedelis by V. Stepanavičienè in 1982. Later, this lake was disturbed by fish farming and became an utterly unfit habitat for $N$. gracilis. Finally, in the BILAS herbarium, a specimen collected in Lake Vištytis was found, and it was determined as $N$. gracilis by Trainauskaite in 1969 . The herbarium sheet consists of two species, N. mucronata and $N$. gracilis, which is the only known sample of this species. Because of the lack of data, N. gracilis is not included in the list of protected species, although it could be found in the waters of Lithuania.

Nitella mucronata (A. Braun) Miq. (Fig. 17)

Nitella mucronata is distributed in all continents except Australia (KoRsch, 2016). Although N. mucronata is widespread in Europe, it is red-listed species (BECKER, 2016).

The references of the early 19th century do not mention N. mucronata in Lithuania. However, several specimens collected in 1823 and stored in the
WI Herbarium as Chara or Nitella gracilis belong to N. mucronata. We suppose that specimens mentioned by Mowszowicz (1957) as $N$. gracilis and collected in the environments of Vilnius (unlabelled specimens in WI), also belong to $N$. mucronata. After extensive surveys of lakes in the second half of the 20th century, N. mucronata was considered widespread throughout the country (ك̌SARKINIENÉ, 1961, 1963; TRAINAUSKAITÉ, 1970). The species was recorded in 54 grid cells and 82 water bodies. $N$. mucronata most often was found in lakes, also recorded in ponds in Vilnius city and once found in the water reservoir. During the last three decades, the occurrence of $N$. mucronata has been recorded in 25 new grid cells, and in several locations, it has been found repeatedly. It is a relatively common species, and recently, it has not been included in the Red Data Book; however, it has been red-listed before (SINKEVIČIENĖ, 2007). Nevertheless, its state should be monitored, as there are several localities, where the species has not been found repeatedly, especially in the lakes of the Samogitian Upland and in the Curonian Lagoon.

\section{Nitella syncarpa (Thuill.) Chev. (Fig. 18)}

Nitella syncarpa has Eurasian distribution (KoR$\mathrm{SCH}, 2018$ ). In Europe, the species is recorded in many countries; however, in most of them, it is endangered (BECKer, 2016).

In Lithuania, $N$. syncarpa was first reported as Chara syncarpa Pers. in the ditch near Alsakiai by WolfaAng (1824). In the collection of the 19th century, one herbarium specimen of $N$. syncarpa was found, which was identified as $N$. capillaris (Krok.) J. Groves et Bull. Webst. (MinKEvIČIIUS \&Trainauskaité, 1970). Plants were collected from Lake Viesai (white dot), situated close to Alsakiai. Mowszowicz (1947) has reported this species from standing water bodies directly in Vilnius city; however, no corresponding herbarium specimens were preserved. Later, Trainauskaité (1970) has characterised $N$. syncarpa as quite rare, but scattered throughout the country. This species was recorded in 17 water bodies situated in 11 grid cells. The distribution of $N$. syncarpa is related to water bodies of uplands. Many findings are in lakes, but only solitary plants usually occur. It seems that the most suitable habitats for $N$. syncarpa are in small artificial water bodies. In 2003, an abundant population of this spe- 


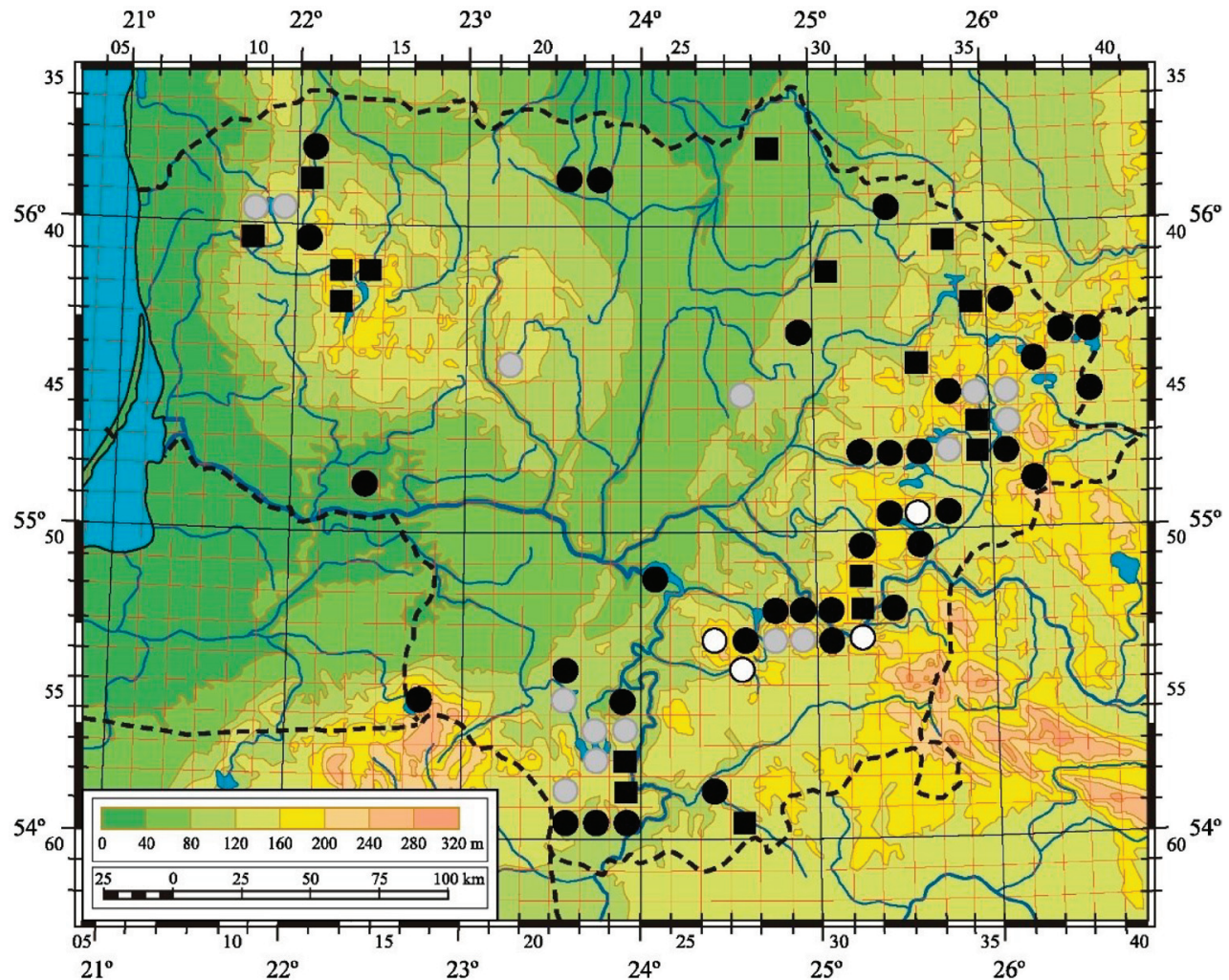

Fig. 15. Distribution of Nitella flexilis in Lithuania. For the explanation of symbols, see Table 1

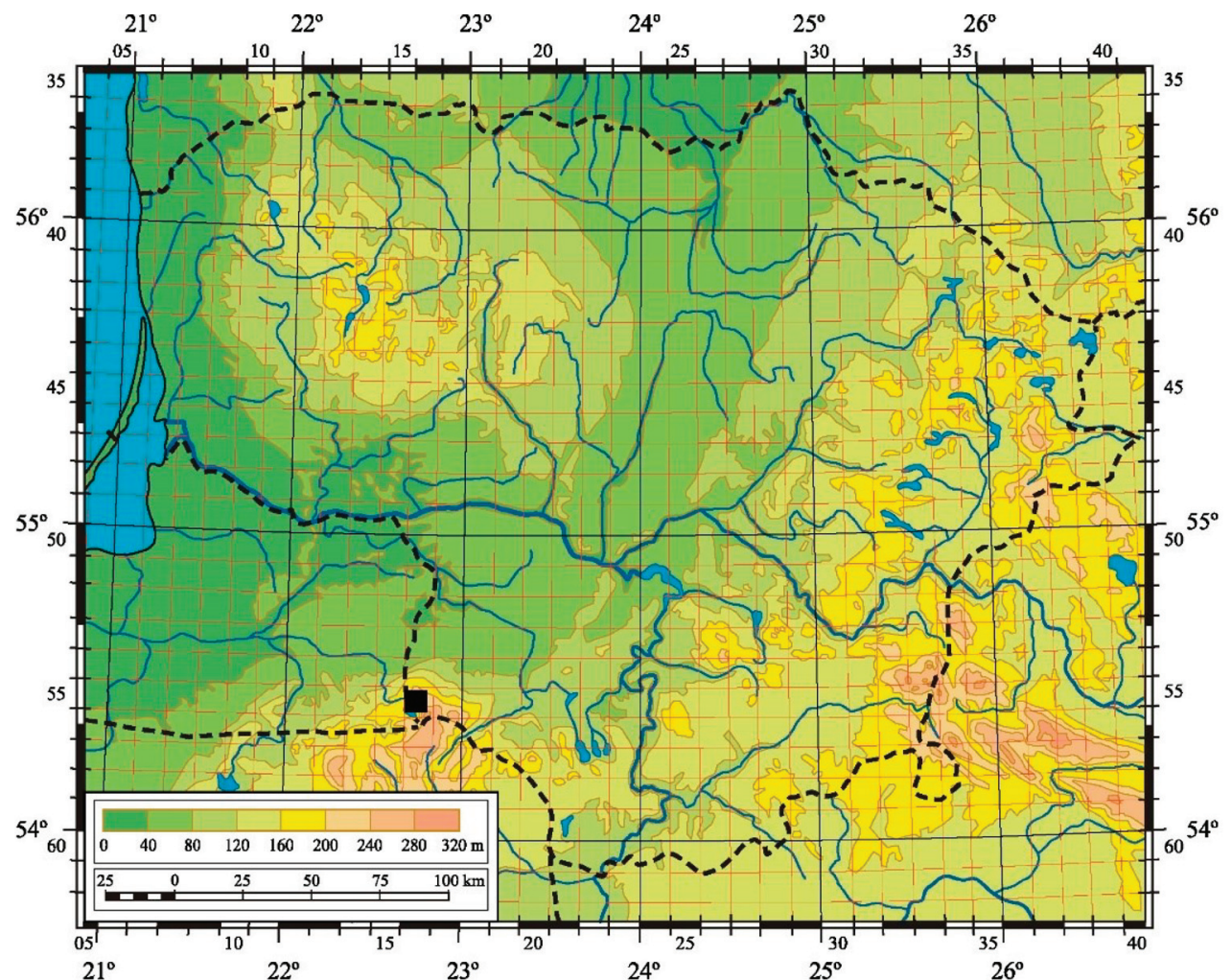

Fig. 16. Distribution of Nitella gracilis in Lithuania. For the explanation of symbols, see Table 1 


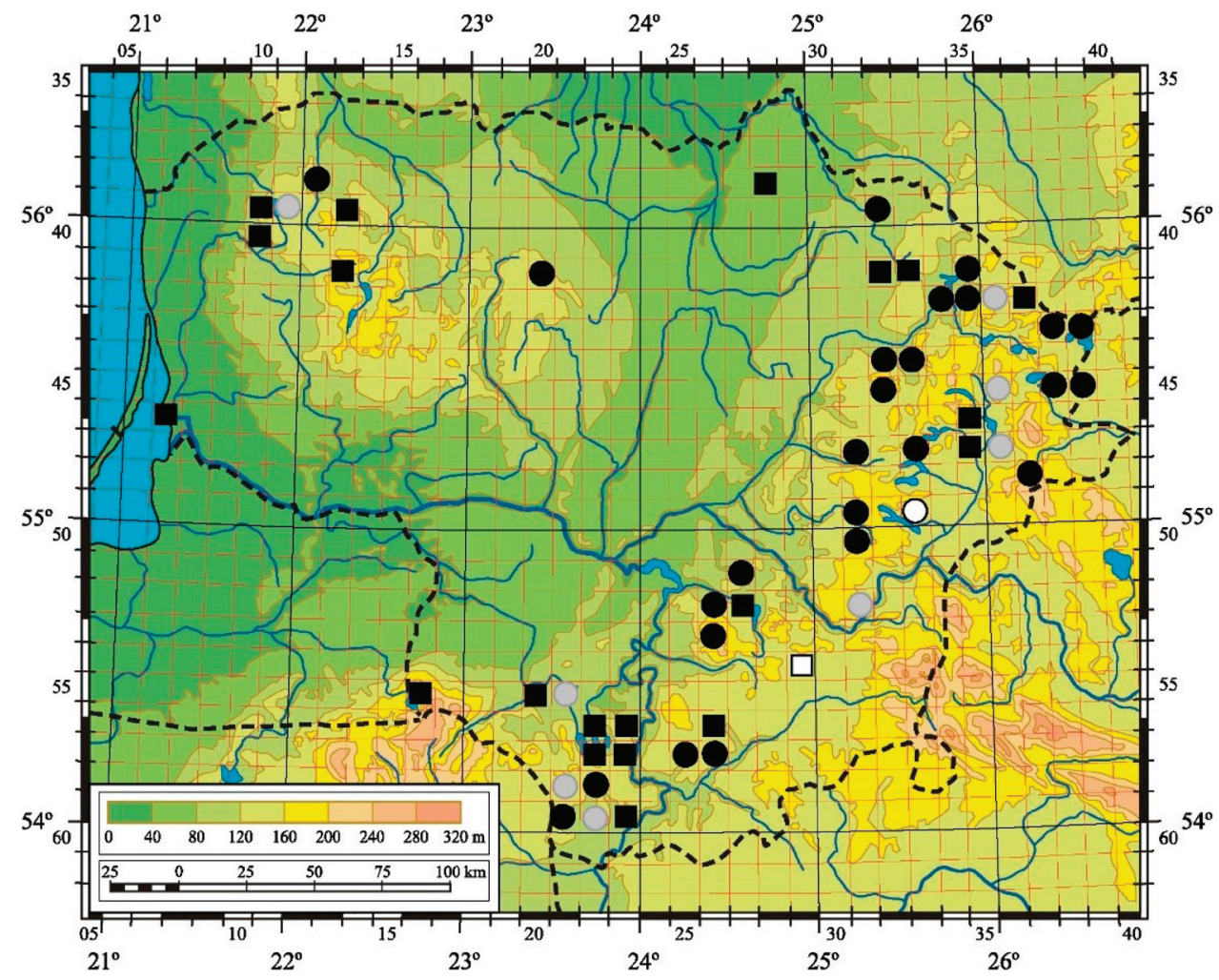

Fig. 17. Distribution of Nitella mucronata in Lithuania. For the explanation of symbols, see Table 1

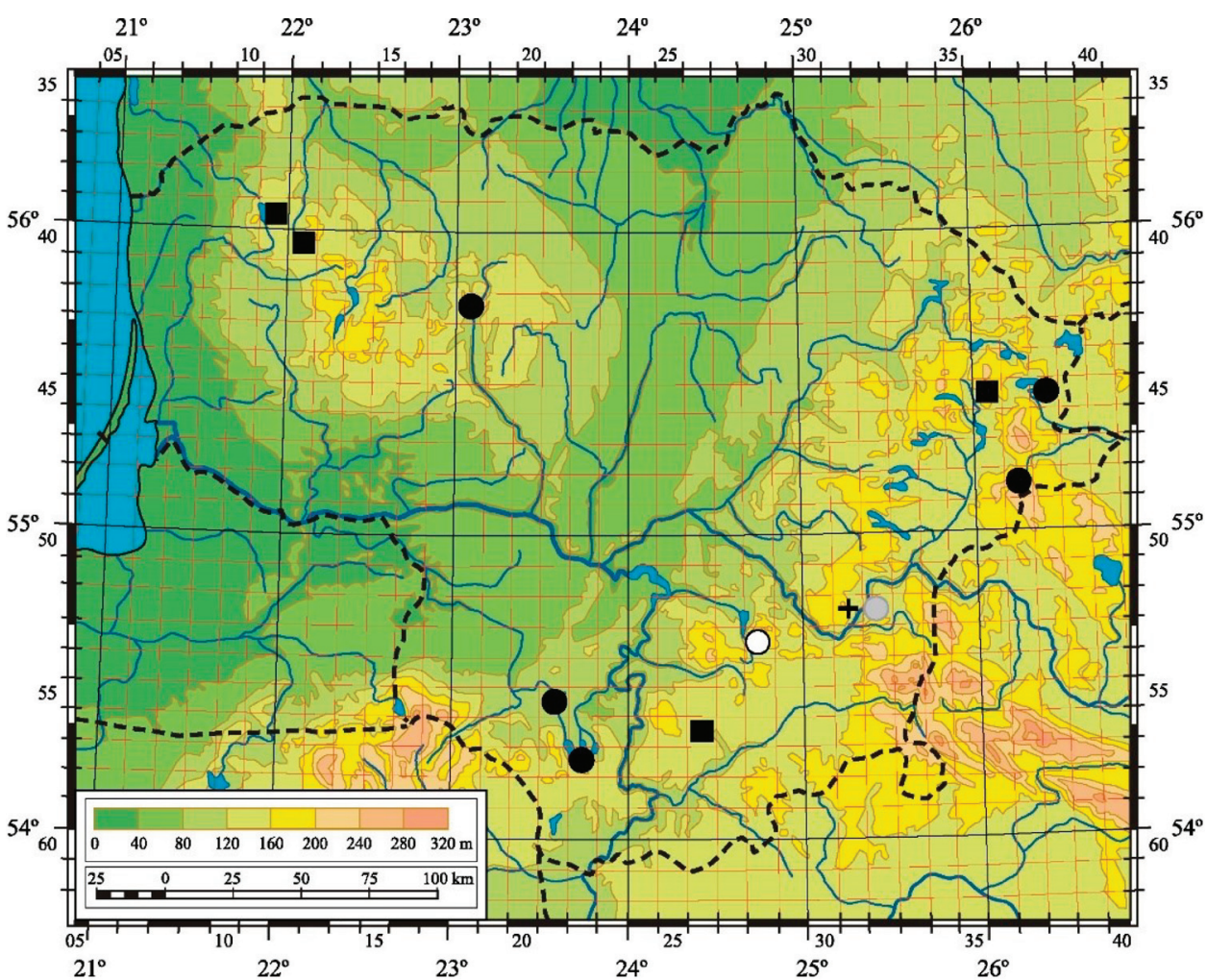

Fig. 18. Distribution of Nitella syncarpa in Lithuania. For the explanation of symbols, see Table 1 
cies was detected in artificial ponds excavated for the European pond turtle. However, in abandoned ponds, $N$. syncarpa disappears because of its poor competitive abilities. The transiency of the habitats and the difficulties in ensuring their protection were reasons why $N$. syncarpa was not included in the latest list of protected species. However, it was red-listed earlier (SINKEVIČIENĖ, 2017) and currently is considered endangered.

Nitellopsis obtusa (Desv.) J. Groves (Fig. 19)

Nitellopsis obtusa has native distribution in Europe and Asia; however, several decades ago, it was introduced to North America, where recently it has been spreading (Korsch, 2018). Although N. obtusa is widespread in Europe, it is endangered in many countries (BECKER, 2016).

In Lithuania, the first specimens of $N$. obtusa were collected in 1823 (the environs of Skurbutenai; white dot). It was named Chara flexilis (WI herbarium), C. translucens (WolfGANG, 1824; Gorski, 1849), C. reichenbachii (GorsKI, 1849), but not included in the main list published at that time by
Gorski (1830). In the middle of the 20th century, after investigations of macrophytes in lakes of eastern and southern Lithuania, it was found that N. obtusa (Tolypellopsis steligera) was quite common species (ŠARKINIENĖ, 1961) forming large stands deeper than usual Chara distribution zone (ŠARKINIENE⿺, 1963). After an extensive inventory of the Characeae by Trainauskaité (1970), N. obtusa was characterised as "a widespread in lakes throughout the country". Additionally, it was found in the Curonian Lagoon (MinkevičIus \& Pipinys, 1959). Nitellopsis obtusa was recorded in 91 grid cells and 177 water bodies, and it is among the common species in Lithuania. Its localities are mainly concentrated in Lakelands of uplands. Lakes and water reservoirs are the most critical habitats for this species. It still grows in the Curonian Lagoon as well.

\section{Tolypella nidifica (O.F. Müll.) A. Braun} (Fig. 20)

Tolypella nidifica is distributed in the Northern Hemisphere (North America, Europe, North Africa, Asia) and Australia (UrbaniaK, 2003; Korsch,

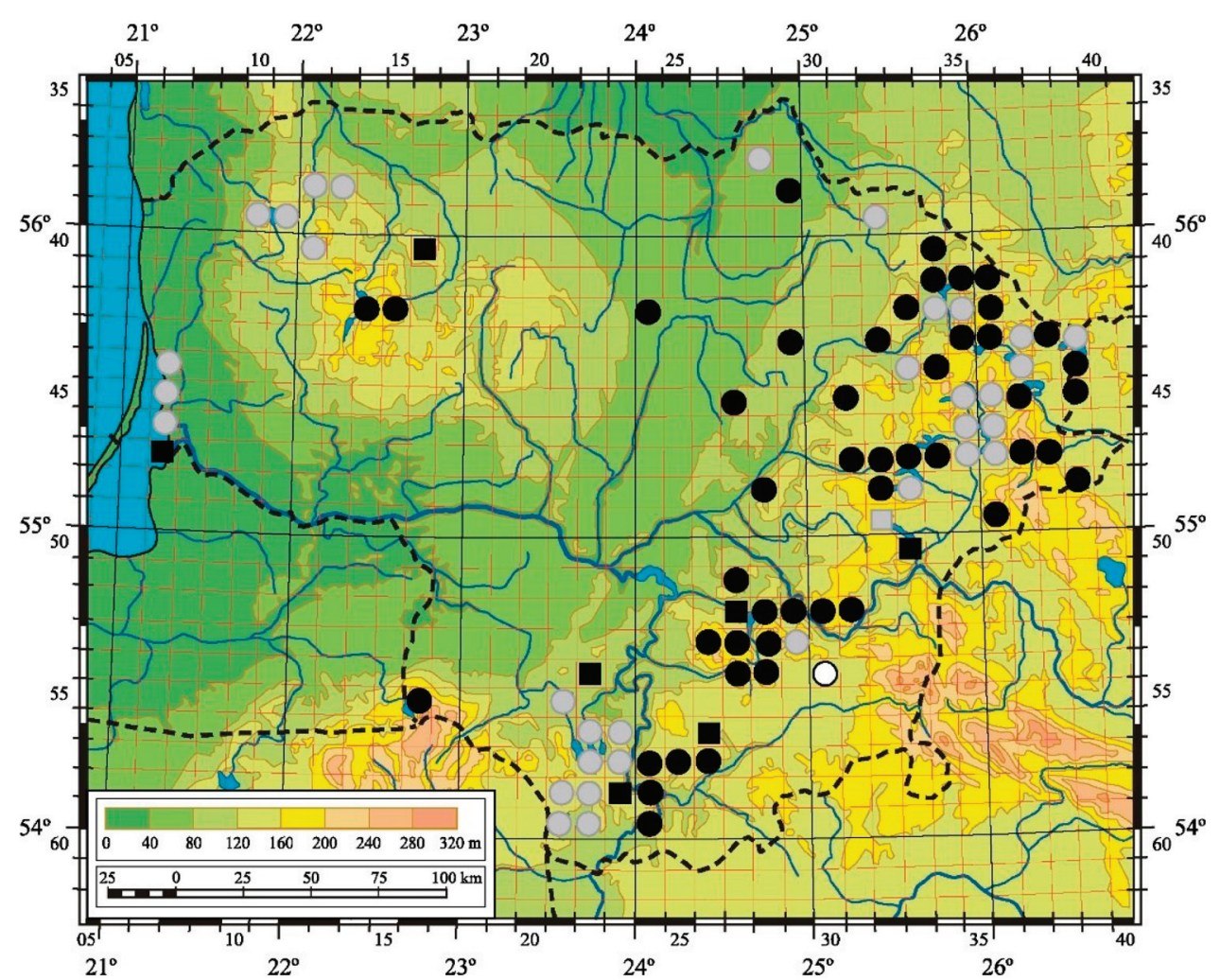

Fig. 19. Distribution of Nitellopsis obtusa in Lithuania. For the explanation of symbols, see Table 1 


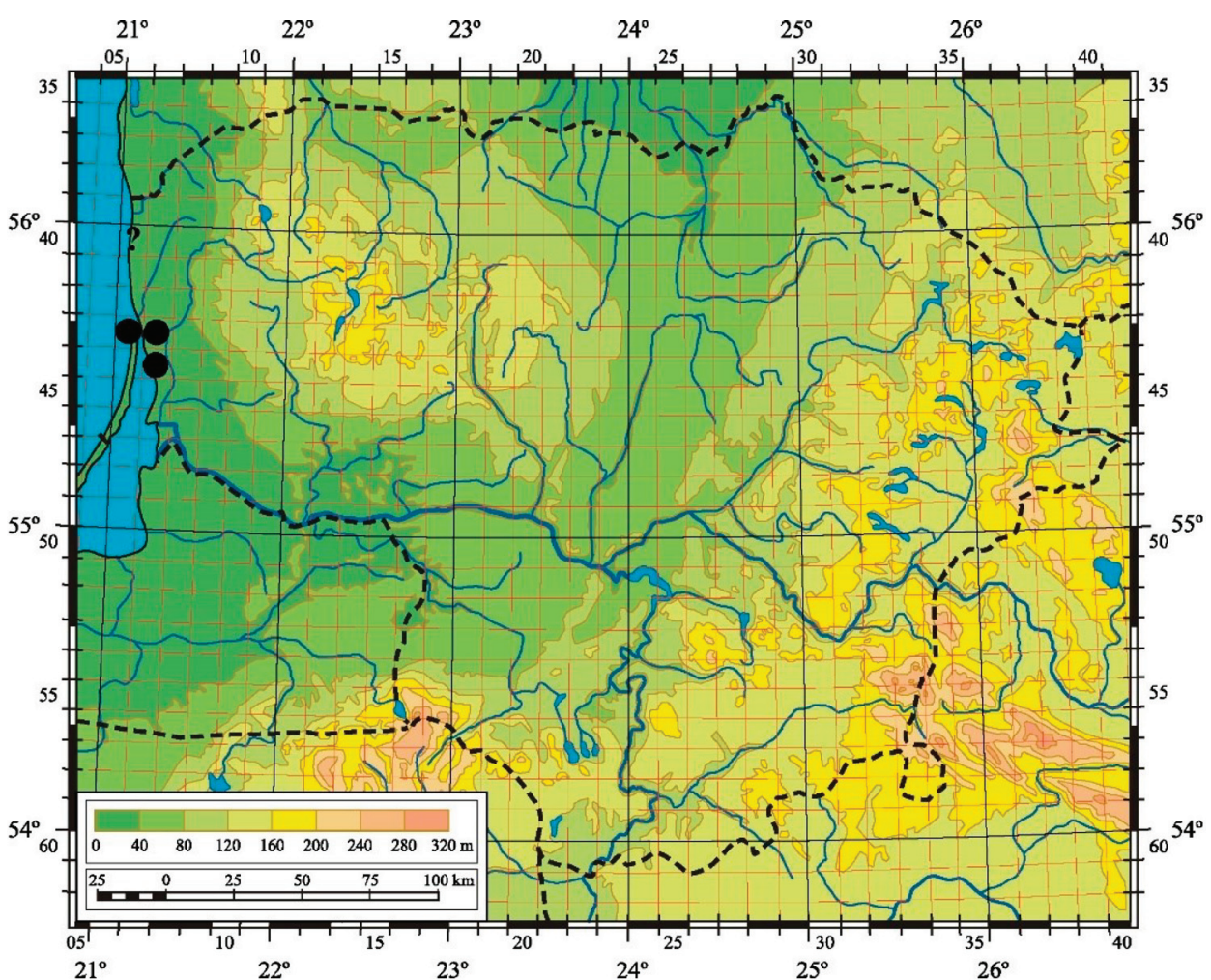

Fig. 20. Distribution of Tolypella nidifica in Lithuania. For the explanation of symbols, see Table 1

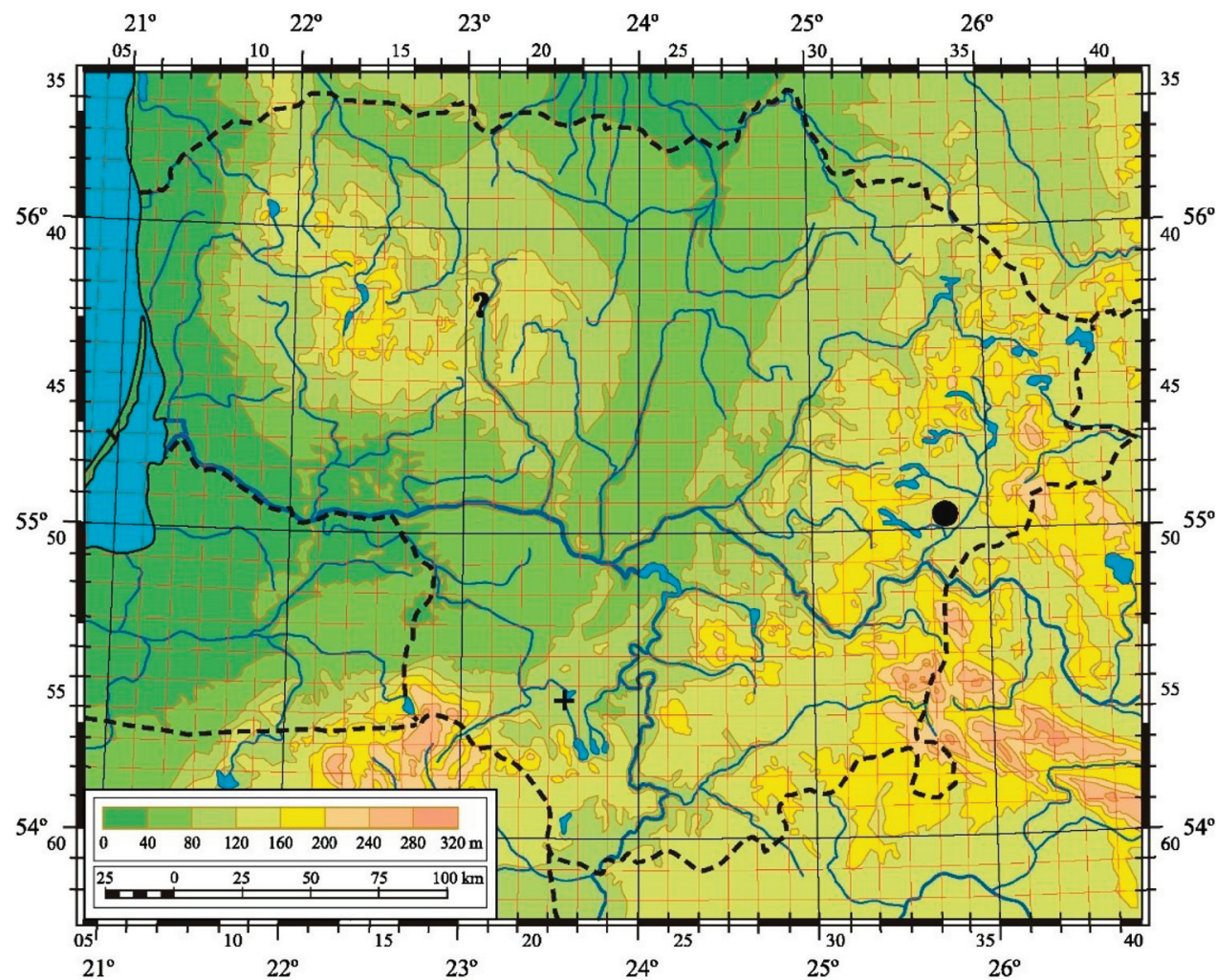

Fig. 21. Distribution of Tolypella prolifera in Lithuania. For the explanation of symbols, see Table 1 
2018). It has been recorded from all countries around the Baltic Sea (Urbaniak, 2003).

In Lithuania, T. nidifica was first recorded by RUPRECHT (1845) from the Baltic Sea coast near Palanga. Currently, there are no data on the occurrence of the species at this site, probably because the habitats have been heavily altered and urbanised. Now, T. nidifica, as well as other Characeae species of brackish water, is known from scattered locations in the north-eastern part of the Curonian Lagoon (SINKEvičIENE, 2004; SINKEVIČIENĖ et al., 2017). Therefore, this very scarce species is included in the Red Data Book and classified as endangered (SINKEVIČIENĖ, 2007, 2017, 2021).

Tolypella prolifera (Ziz ex A. Braun) Leonh. (Fig. 21)

Tolypella prolifera is distributed in North America, Europe and Asia (Korsch, 2018). In Europe, it has been detected in many countries; however, it is rare and threatened (VAN DE WEYER, 2016; BECKER, 2016).

In Lithuania, as in many European countries (VAN DE Weyer, 2016), T. prolifera occurs in shallow warm waters. It was first recorded only in the 20th century in Lake Žuvintas ( ̌́ sequently disappeared (ŠARKINIENĖ, TraINAUSKAITE 1993). Its recent occurrence in a small artificial pond (Šiauliai district) is also doubtful (SINKEVIČIENĖ, 1996, 2007). The most recent locality in Arnionys fishpond has not been reinvestigated. The species was included in the Red Data Book in 1992 (Trainauskaité, 1992; SINKEVIČIENĖ, 2007). However, this very scarce species is not included in the new edition of the Red Data Book, because the protection of its habitats is complicated by the specific use of fishponds and small artificial water bodies.

\section{Distribution and threats}

The distribution of the Characeae species was recorded in 251 mapping grid cells $(42 \%$ of the total number 593). Herbarium specimens were collected from 693 water bodies, mainly lakes. The most significant number of species (19 of 21) was registered in the grid cells of the southwestern part of the country (grid cell 5722), which includes large Lakes Dusia, Meteliai, Obelija and Seirijis. The lakes have periodically been investigated since the middle of the 20th century. Many smaller water bodies have also been studied recently. The second rich in species (17) grid cell (5521) is situated close to the first one. It covers the territory of the best-studied Lake Žuvintas and the first protected area in Lithuania, the Žuvintas Strict Nature Reserve (currently Žuvintas Biosphere Reserve). The same number of species (17) was recorded for the grid cell 5328, situated westward from Vilnius and having long-term investigation history, starting from the 19th century. Sixteen species were recorded in the grid cell covering the northern part of Vilnius city (5231). In about a half of grid cells, one or two species only were registered. In most cases, the number of water bodies, where the Characeae species occurred, significantly exceeded the number of the grid cells, except for several rare species.

Chara globularis is the most common species, recorded in 150 grid cells and more than 250 water bodies (Fig. 22). A group of 10 species (C. aspera, C. contraria, C. filiformis, C. subspinosa, C. tomentosa, C. virgata, C. vulgaris, Nitella mucronata, N. flexilis, Nitellopsis obtusa), recorded in less than 100 and more than 50 grid cells, should also be considered common species. Two species (C. papillosa, C. strigosa) were recorded in less than 50 grid cells and can be considered quite common species. The study also highlighted a group of rare species in which records of Nitella syncarpa only exceeded ten grid cells. The threats for eight species, which have been included in the Red Data Book (SinkevičIENĖ, 2007), were assessed following the IUCN Guidelines and Criteria (IUCN 2012, 2017). Six species were attributed to the threat categories; however, the list of protected species (SINKEVIČIENÉ, 2021) included five (Table 2).

Table 2. Evaluation of the rare Characeae species, applying the IUCN criteria and categories. Species included into the Red Data Book are marked by bold typeface

\begin{tabular}{|l|c|c|}
\hline \multicolumn{1}{|c|}{ Species name } & $\begin{array}{c}\text { IUCN } \\
\text { category }\end{array}$ & IUCN criteria \\
\hline Chara baltica & EN & B1ab(iii) + 2ab(iii) \\
\hline Chara canescens & CR & B1ab(iii) + 2ab(iii) \\
\hline Lychnothamnus barbatus & EN & B1ab(iii) + 2ab(iii) \\
\hline Nitella confervacea & CR & A2ac \\
\hline Nitella syncarpa & EN & B2ab(iii) \\
\hline Tolypella nidifica & EN & B1ab(iii) \\
\hline Tolypella prolifera & DD & - \\
\hline Nitella gracilis & DD & - \\
\hline
\end{tabular}




\section{Comments about unconfirmed species}

Chara aculeolata Kütz. in Rchb.

In Lithuania, C. aculeolata has been treated as a synonym of $C$. intermedia A. Braun. (Minkevičıus \& Trainauskaité, 1970; Trainauskaité, 1970; ŠARKINIENE \& TRAINAUSKAITÉ, 1973) since the middle of the 20th century for quite a long time. According to the current nomenclature (SCHUBERT \& al., 2016), the correct name of Chara intermedia is C. papillosa Kütz. Chara aculeolata (synonym C. polyacantha A. Braun ex A. Braun) is another species that has never been confirmed occurring in Lithuania.

\section{Chara connivens Salzm. ex A. Braun}

C. connivens A. Braun has been reported by MinkevičIus \& Trainauskaité (1970) in the review about the Characeae collection by S.B. Gorski of the 19th century in the WI Herbarium. ŠARKINIENE (1961) has reported this species in one lake (Trakai distr.). TrainAuSKaité (1970) has considered this species as common and distributed in lakes throughout the country. LUTHER (1979), based on the revision of several specimens from the 19th and the 20th centuries, has not confirmed the occurrence of $C$. connivens in freshwaters of Lithuania. The specimens labelled as C. connivens in the herbaria (WI and BILAS) mainly belong to $C$. globularis. The species has not been found during the investigations of the Curonian Lagoon (SINKEVIČIENĖ, 2004; SinKEviČIENĖ et al., 2017). Chara connivens is mainly distributed in brackish waters (TORN \& MARTIN, 2003); however, morphotypes resembling $C$. connivens of dioecious Chara occur in freshwater, which genetically is intermediate between $C$. connivens and monoecious $C$. globularis (TRBojević et al., 2020). These plants can also grow in Lithuania, but have not been recorded.

\section{Chara crassicaulis Schleich.}

Chara crassicaulis at the rank of species has been reported by Mowszowicz (1947). Recently, this taxon has been treated as $C$. vulgaris $\mathrm{L}$. var. crassicaulis (Schleich. ex A.Braun) Kütz. (Korsch, 2016).

Chara foliosa auct. (= C. braunii C.C. Gmelin) Mowszowicz (1947) has supposed that Chara foliosa, mentioned by WolfGang (1822), as possibly collected in the vicinity of Vilnius, is $C$. coronata
Zis. (= C. braunii). Mowszowicz (1947) himself, as well as Minkevičius \& Trainauskaite (1970), have not mentioned anything about specimens of this species available in the collection of the 19th century in the WI Herbarium. C. braunii has not been found in Lithuania till now.

\section{Chara fragifera Durieu de Maisonneuve}

Chara fragifera has been reported by Trainauskaitė (1970), ŠarkinienĖ \& Trainauskaitė (1973), SinkeviČIENĖ (1994), BALEviČIUS (1998). Examined herbarium specimens in WI and BILAS represent misidentified plants of $C$. globularis. The occurrence of this species also has not been confirmed during an earlier inventory (KosTKEVIČIENE \& SINKEVIČIENĖ, 2008). Furthermore, it seems that the distribution range of this species is further south and does not reach the territory of Lithuania (GUIRY \& GuirY, 2021).

\section{Chara galioides DC.}

The occurrence of $C$. galioides in the Curonian Lagoon has been denied in earlier publications (SinkevičIenĖ, 2004; KostKevičIEnĖ \& SinkevičIenĖ, 2008). The occurrence of brackish water species in the freshwater part of the Curonian Lagoon, near the estuary of the River Nemunas (TRAINAUSKaITÉ, 1978), remains unlikely. Furthermore, herbarium specimens confirming its occurrence in the area are absent.

\section{Chara hispida L.}

Chara hispida is distributed in Europe, North Africa and West Asia (GREgor et al., 2014). It morphologically is similar to C. subspinosa and can be easily confused, especially using some determination keys (SCHUBert et al., 2016). In Lithuania, even though $C$. hispida has been mentioned in the literature since the 19th century (JunDZIŁE, 1791; WolfGANG，1822; JUNDZIŁE, 1830; MowszowicZ，1954; TrainausKaitė, 1970; ŠarkinienĖ \& TrainausKaitė, 1973; SINKEVIČIENĖ, 1994, 2007), there are no herbarium specimens, which could confirm its occurrence doubtlessly. Part of the specimens in the herbaria labelled as $C$. hispida belong to C. papillosa. Another part of the specimens belongs to C. subspinosa and intermediate forms between it and C. hispida. During the last revision of samples, just four specimens were attributed to $C$. hispida only tentatively. Plants 
were collected from the straightened riverbed, gravel quarry and two lakes. C. subspinosa seems to be most common in the lakes of Lithuania, whereas the actual occurrence and distribution of C. hispida remain unclear.

\section{Chara polyacantha A. Braun}

Chara polyacantha has been referred by ŠARKinienĖ (1961, 1968), Trainauskaité (1970), ŠARKINIENE \& TRAINAUSKAITE (1973) and SinKEVIČIENĖ (1994). The revised specimens, which were labelled as C. polyacantha (WI and BILAS), were identified as C. strigosa (SINKEVIČIENĖ, 2007; KostKeVIČIENĖ \& SinKEVIČIENĖ, 2008).

Chara polyacantha A. Braun is a synonym of C. aculeolata Kütz. (SCHUBert et al., 2016). As mentioned above, in the references concerning the territory of Lithuania (MINKEviČIUS \& TRAINAUSKAITĖ, 1970; TrainausKaité, 1970; ŠarkinienĖ \& TrainausKaité, 1973), C. aculeolata Kütz. has been considered as a synonym of $C$. intermedia A. Braun. In fact, Chara aculeolata Kütz. (= Chara polyacantha A. Braun) has never been found in Lithuania.

\section{Chara scoparia Bauer (=C. baueri A. Braun)}

TrainausKaite (1970) has reported the occurrence of $C$. scoparia in the western part of the country and indicated it as growing in a drainage ditch. The species has also been listed by ŠARKINIENE \& TrainausKaité (1973). Chara baueri has even been included in the Red Data Book (TrainauskaitE, 1992); however, there are no herbarium specimens of this species found during the previous inventory (KostKevičIEnĖ \& SinkevičIENÉ, 2008) and the current revision.

\section{Nitella capillaris (Krock.) J. Groves et Bull.- Webst.}

The specimen in the WI Herbarium, collected in the 19th century and, probably by J. Mowszowicz identified as $N$. capitata (Nees) C. Agardh, has not been listed in his published account (Mowszowicz, 1947). Later, this specimen has been reidentified as $N$. capillaris Krock. by I. Trainauskaite and reported by Minkevičius \& Trainauskaité (1970). In our opinion, this specimen belongs to morphologically similar species $N$. syncarpa. Nitella capillaris has also been referred by TrainAuSKaIté (1970),
ŠARKINIENĖ \& TRAINAUSKaité $(1973,1993)$; however, revised herbarium specimens belong to other Nitella species.

\section{Nitella hyalina (DC.) C. Agardh}

Nitella hyalina has been reported by MowszowICZ (1954) with the indicated locality of collection in Lake Totoriškès. Unfortunately, this specimen, possibly collected in 1940, was not found in the collection stored in the WI Herbarium. Therefore, the occurrence of species in Lithuania's waters has not been confirmed so far.

\section{Nitella opaca (C. Agardh ex Bruzelius) C. Agardh}

In the comments about $N$. flexilis, we mentioned that $N$. opaca in Lithuania is neither confirmed nor disproved. In different periods of investigations, either $N$. opaca or $N$. flexilis have been reported as a more common species. Based on the available herbarium material, $N$. flexilis appears to be more common. Among the herbarium specimens, we did not find fertile dioecious plants of $N$. opaca. This species is considered a typical springtime species whose oospores could be already ripened in April-May, but this is characteristic of shallow waters only (BECKER \& WolfF, 2016). Small shallow water bodies are poorly investigated in Lithuania; therefore, future detection of this species is plausible.

\section{Nitella tenuissima (Desv.) Kütz.}

Nitella tenuissima has been mentioned only by Mowszowicz (1954), from Lake Totoriškès. However, no herbarium specimens are available in the herbaria of Lithuania. In the Herbarium of Algae of Adam Mickiewicz University in Poznan (POZA), the specimen collected on 27 August 1936 by I. Dąbkowska in Švenčionys Region is preserved. The specimen has been determined by J. Karpiński as Nitella tenuissima. This specimen was not revised during this study.

\section{Nitella translucens (Pers.) C. Agardh}

Mowszowicz (1954) has considered that Chara translucens Pers. recorded by WolfGang (1824), is Nitella translucens. However, the drawing of Chara translucens Pers. by Gorski (1849, Table X, Fig. 2), represents the male plant of Nitellopsis obtusa. The 
herbarium envelope stored in the collection of the 19th century and named "Chara Nr. 7. - translucens-flexilis" contains specimens of Nitellopsis obtusa, as it has been referred to by MinKEviČIus \& TRAINAuSKaité (1970). We did not find specimens of $N$. translucens in the herbaria of Lithuania.

\section{DISCUSSION}

As a result of the current revision of herbaria collections and analysis of other available data accumulated since the 19th century, 21 Characeae species in the water bodies of Lithuania was confirmed. The number of the Characeae species determined in Lithuania is close to that in Finland (LANGANGEN et al., 2009), the Netherlands (SimONS \& NAT, 1996), Estonia (ToRn et al., 2015), and slightly lower than in the neighbour Latvia (Zviedre \& DeķERE, 2005), Norway (Langangen, 2007) and the Czech Republic (CAIsova \& GĄBKA, 2009), accounting 25-26 species. The number of the Characeae species in Lithuania is significantly lower than in countries with a much larger area, such as Poland (URBANIAK \& GąbKa, 2014), Germany (Arbeitsgruppe Characeen Deutschlands, 2016) or Sweden (Blindow et al., 2007), where from 34 to 38 species have been recorded. The countries mentioned above are richer in the Characeae species due to significantly larger area and greater diversity of habitats than Lithuania and also because the diversity of species is much better studied. Although investigations on the Characeae covered all the territory of Lithuania in 1945-1990 and 1990-2020, certain types of aquatic habitats have not been studied, or studied only fragmentary. Most of the investigations were carried out in lakes, and consequently, most of the herbaria specimens were collected in lakes.

Several species could be added to the list of the Characeae of Lithuania in the future. In this study, we did not include Nitella opaca, which in a sterile stage cannot be distinguished from Nitella flexilis (BeCKer \& WolfF, 2016). Aiming to confirm the occurrence of Nitella opaca in the country, noteworthy studies in springtime are necessary to detect fertile male and female individuals of this species or plants with ripe oospores. The second uncertain species is Chara hispida. We did not find typical specimens of C. hispida in the studied herbaria. Intermediate forms between C. hispida and C. subspinosa were recorded only. Thus, further studies can confirm the existence of $C$. hispida and several species of the genus Nitella in the waters of Lithuania. Records of the Characeae species covered less than half of grid cells, mainly including natural territories; however, its occurrence, especially of some species, is very likely in the territories impacted by human activities.

The most significant number of species have been reported from 1945 to 1990. Trainauskaité (1970), ŠARKINIENĖ \& TRAINAUSKAité (1973) have listed 24 Characeae species in the water bodies of Lithuania (Table 3). The previous analysis (KosTKEVIČIENE \& SinKEVIČIENÉ, 2008) and recent revision of the herbarium specimens did not confirm the occurrence of Chara connivens, $C$. galioides and C. fragifera, and their occurrence in the country is hardly possible. The specimens of Nitella capillaris, N. opaca, Chara hispida and C. baueri (C. scoparia) also were not found in the studied herbaria. Still, the presence of these species in Lithuania is expected.

Studies on the Characeae were quite intensive from 1990 to 2020; however, the number of recorded species (20 species) was lower than in the previous period (Table 3). The rarest species, Nitella gracilis, was recorded in 1969, and no recent records of this species were made. During this period of investigation, brackish water species $C$. baltica, $C$. canescens and Tolypella nidifica have been added to the list, and Nitella confervacea after a long time, has been found again (SINKEvičIENĖ, 2004, 2007; KostKeviČIENĖ \& SinKEVIČIENĖ, 2008). Eleven Characeae species are common in Lithuania, and their distribution as well as abundance have generally remained unchanged. Chara papillosa and C. strigosa are not rare species, but particular attention should be paid to their observations. C. papillosa is insufficiently studied; however, C. strigosa has recently disappeared from several localities. The most attention should be paid to the group of rare and threatened species. Although the lack of data for evaluation according to the IUCN criteria (DD) was identified only for Nitella gracilis and Tolypella prolifera, data updates are also necessary for other species. Although these two species and Nitella syncarpa were evaluated as endangered (EN), they are not included in the list of legally protected species of Lithuania. This list and the Red Data Book include five species (Chara baltica, C. canes- 
Table 3. Species names used during different periods of the Characeae studies in references and on herbarium specimen labels in Lithuania

\begin{tabular}{|c|c|c|c|}
\hline \multicolumn{4}{|c|}{ Period of studies } \\
\hline $1990-2020$ & $1945-1990$ & $1919-1940$ & $1790-1850$ \\
\hline Chara aspera Willd. & C. aspera Willd. & C. aspera (Deth.) Willd. & $\begin{array}{l}\text { C. pusilla Floerke, } \\
\text { C. aspera DC. }\end{array}$ \\
\hline \multicolumn{4}{|l|}{$\begin{array}{l}\text { Chara baltica (Hartman) } \\
\text { Bruzelius }\end{array}$} \\
\hline Chara canescens Loisel. & & & C. crinita Wallr. \\
\hline $\begin{array}{l}\text { Chara contraria } \\
\text { A. Braun ex Kütz. }\end{array}$ & C. contraria Kütz. & & \\
\hline Chara filiformis Hertzsch & C. jubata A.Braun & C. tyzenhauzi Gorski & $\begin{array}{l}\text { C. funicularis Pers., } \\
\text { C. tyzenhauzi Gorski }\end{array}$ \\
\hline Chara globularis Thuill. & C. fragilis Desv. & C. fragilis Desv. & $\begin{array}{l}\text { C. pulchella Wallr., } \\
\text { C. articulata Gorski, } \\
\text { C. dicarpa } \text { Gorski }\end{array}$ \\
\hline Chara papillosa Kütz. & C. aculeolata Kütz. & C. intermedia A.Braun & \\
\hline $\begin{array}{l}\text { Chara strigosa } \\
\text { A.Braun }\end{array}$ & C. polyacantha A.Braun & & \\
\hline Chara subspinosa Rupr. & C. rudis A.Braun & C. rudis A.Braun & C. hispida $\mathrm{L}$. \\
\hline Chara tomentosa $\mathrm{L}$. & $\begin{array}{l}\text { C. ceratophylla Wallr., } \\
\text { C. tomentosa L. }\end{array}$ & C. ceratophylla Wallr. & $\begin{array}{l}\text { C. ceratophylla Wallr, } \\
\text { C. tomentosa } \mathrm{L} \text {. }\end{array}$ \\
\hline Chara virgata Kütz. & C. delicatula C.Agardh & C. delicatula C.Agardh & C. elegans \\
\hline Chara vulgaris $\mathrm{L}$. & $\begin{array}{l}\text { C. foetida A.Braun, } \\
\text { C. vulgaris L., } \\
\text { C. crassicaulis Schleich. }\end{array}$ & $\begin{array}{l}\text { C. foetida A.Braun, } \\
\text { C. crassicaulis Schleich. }\end{array}$ & C.vulgaris $\mathrm{L}$. \\
\hline $\begin{array}{l}\text { Lychnothamnus barbatus } \\
\text { (Meyen) Leonh. }\end{array}$ & $\begin{array}{l}\text { L. barbatus (Meyen) } \\
\text { Leonh. }\end{array}$ & & $\begin{array}{l}\text { Chara radiata Gorski } \\
\text { C. brachiata Dierb. }\end{array}$ \\
\hline $\begin{array}{l}\text { Nitella confervacea (Bréb.) } \\
\text { A.Braun ex Leonh. }\end{array}$ & & N. batrachosperma (Rchb.) A.Braun & C. batrachosperma Pers. \\
\hline $\begin{array}{l}\text { Nitella flexilis } \\
\text { (L.) C.Agardh }\end{array}$ & N. flexilis (L.) C.Agardh & N. flexilis (L.) C.Agardh & C. flexilis L.? \\
\hline $\begin{array}{l}\text { Nitella mucronata } \\
\text { (A. Braun) Miq. }\end{array}$ & $\begin{array}{l}\text { N. mucronata (A.Braun) } \\
\text { Miq. }\end{array}$ & & C. gracilis \\
\hline $\begin{array}{l}\text { Nitella syncarpa (Thuill.) } \\
\text { Chev. }\end{array}$ & N. syncarpa (Thuill.) Kütz. & N. syncarpa (Thuill.) Kütz. & C. syncarpa Pers. \\
\hline $\begin{array}{l}\text { Nitellopsis obtusa (Desv.) } \\
\text { J.Groves }\end{array}$ & $\begin{array}{l}\text { N. obtusa (Desv.) J.Groves, } \\
\text { Tolypellopsis stelligera } \\
\text { (Bauer) Mig. }\end{array}$ & T. stelligera (Bauer) Mig. & $\begin{array}{l}\text { C. reichenbachii Gorski, } \\
\text { C. translucens Gorski }\end{array}$ \\
\hline $\begin{array}{l}\text { Tolypella nidifica } \\
\text { (O.F. Müll.) A.Braun }\end{array}$ & & & $\begin{array}{l}\text { T. nidifica (Müll.) v. } \\
\text { Leonhardi }\end{array}$ \\
\hline \multirow{12}{*}{$\begin{array}{l}\text { Tolypella prolifera } \\
\text { (Ziz ex A.Braun) Leonh. }\end{array}$} & T. prolifera (Ziz.) Leonh. & & \\
\hline & Nitella gracilis C.Agardh & N. gracilis (Smith) C.Agardh & \\
\hline & $\begin{array}{l}\text { Nitella capillaris (Krock.) } \\
\text { J.Groves \& Bull.-Webst. }\end{array}$ & & \\
\hline & Nitella opaca C.Agardh & & \\
\hline & Chara hispida L. & Chara hispida L. & Chara hispida L. \\
\hline & Chara scoparia Bauer & & \\
\hline & Chara connivens A.Braun & & \\
\hline & Chara fragifera Durieu. & & \\
\hline & Chara galioides DC. & & \\
\hline & & Nitella hyalina (DC.) C.Agardh & \\
\hline & & N. tenuissima (Desv.) Kütz. & \\
\hline & & N. translucens (Pers.) C.Agardh & C. translucens Gorski \\
\hline
\end{tabular}


cens, Lychnothamnus barbatus, Nitella confervacea, Tolypella nidifica) (SINKEvičIENĖ, 2021) of eight evaluated according to the IUCN criteria. Other species are not included into the list of protected species not only because of the lack of data, but also because the measures for the conservation of annual plants are quite complicated and insufficiently elaborated.

During the first period of investigations on the Characeae, starting at the beginning of the 19th and ending at the beginning of the 20th century, 15 or 17 species occurring in the vicinities of Vilnius city have been recorded. Although the occurrence of several species recorded during this period is doubtful (Nitella hyalina, N. translucens), the revealed species diversity was high for relatively small territory. Therefore, only the typical brackish water species that cannot grow in the vicinities of Vilnius because of the absence of such water bodies were missing in this list.

Recently, a large amount of data on the Characeae has been collected in the monitored water bodies. State water monitoring has been performed in 574 stretches of natural rivers, 248 stretches of changed flows and in 289 natural lakes, 65 ponds and 1 quarry (APlinKos APSAUgos AgenTŪRA, 2013-2015a, b). However, routine monitoring of aquatic plants provides data mainly on common species. Furthermore, poorly collected material during monitoring studies is often challenging to identify. Therefore, the focused studies on the Characeae are still needed and should include small water bodies, recently formed water bodies in quarries, many of which have particularly favourable conditions for the formation of pioneer vegetation and can be a refuge for rare species with a transitional character of occurrence.

\section{REFERENCES}

Aplinkos APSAUgos AgentūRa, 2013-2015a: Ežerų ir tvenkinių monitoringo rezultatai. Makrofitai. - http://vanduo.gamta.lt/cms/ index?rubricId=8ea41f73-9742-4d71-aa10-0a5988713fe5 [accessed 15 July 2021]

Aplinkos apsaugos agentūra, 2013-2015b: Upių, ežerų ir tvenkinių ekologinè būklè - https://aaa. lrv.lt/lt/veiklos-sritys/vanduo/upes-ezerai-irtvenkiniai/upiu-ezeru-ir-tvenkiniu-bukle [accessed 15 July 2021].
Arbeitsgruppe Characeen Deutschlands, 2016: Armleuchteralgen - Die Characeen Deutschlands. - Berlin-Heidelberg.

Bagdonaitė A., 1962: Kai kurių Šiaurès rytų Lietuvos ežerų augalija. - Botanikos klausimai, 2: 115-150.

BALEVIČIENĖ J., ŠARKInIENĖ I., 1988: Ozera. - In: Rastitel'nyj pokrov Nacional'nogo parka Litovskoj SSR: 63-81. - Vilnius.

BALEviČIENĖ J., BALEVIČIUS A., 1994: Antalieptès jūros kraštovaizdžio draustinio vandens telkinių augalija. - Ekologija, 4: 13-22.

BALEvIČIUS A., 1994: Žaliụjų ežerų makrofitų tyrimai. - Ekologija, 4: 20-28.

BaLevičıus A., 1998: Veisèjų regioninio parko ežerų augmenija. - Botanica Lithuanica, 4(3): 267284.

BALEvIČIUS A., 2001: Distribution of Lychnothamnus barbatus community in Lithuania. - Biologija, 2: 70-73.

BeCKer R., 2016: Gefährdung und Schutz von Characeen. - In: Armleuchteralgen. Die Characeen Deutschlands. (Arbeitsgruppe Characeen Deutschlands Lehrstuhl für Ökologie der Universität Rostock, eds): 149-185. - Berlin-Heidelberg.

Becker R., Wolff P., 2016: Nitella flexilis. - In: Armleuchteralgen. Die Characeen Deutschlands. (Arbeitsgruppe Characeen Deutschlands Lehrstuhl für Ökologie der Universität Rostock, eds): 421-434. - Berlin-Heidelberg.

Blindow I., Schubert H., 2003: Chara canescens Desv. et Loisel. in Loisel. 1810. - In: SchUBERT H., Blindow I. (eds), Charophytes of the Baltic Sea: 70-81. - Ruggel.

Buindow I., Krause W., LuUngstrand E., KoistiNEN M., 2007: Bestämningsnyckel för kransalger i Sverige. - Svensk Botanisk Tidskrift, 101: 165-220.

BlÜMel C., 2003: Chara baltica Bruzelius 1824. In: Schubert H., Blindow I. (eds), Charophytes of the Baltic Sea: 53-63. - Ruggel.

BuČas M., SinkevičIené Z., Kataržyté M., VaičIŪtė D., Petkuviené J., Stragauskaitė V., Ilginè R., 2019: How much can the occurrence and coverage of charophytes in an estuarine lagoon (Curonian Lagoon) be explained by environmental factors? - Estuarine, coastal and shelf science, 216: 128-138. 
CAisova L., GąBKa M., 2009: Charophytes (Characeae, Charophyta) in the Czech Republic: taxonomy, autecology and distribution. - Fottea, 9(1): $1-43$.

Corillion R., 1957: Les Charophycées de France et d'Europe occidentale. - Bulletin de la Société Scientifque de Bretagne, 32, Bot. ser. 1: 1-259; 2: 260-499.

Doege A., van De Weyer K., 2016: Chara virgata. In: Armleuchteralgen. Die Characeen Deutschlands. (Arbeitsgruppe Characeen Deutschlands Lehrstuhl für Ökologie der Universität Rostock, eds), 369-379. - Berlin-Heidelberg.

Galinis V., 1963: Keletas naujų Potamogeton formų ir hibridų Lietuvos TSR floroje. - Lietuvos TSR aukštųjų mokyklų mokslo darbai. Biologija, 3: 97-107.

GaLinIS V., 1968: Stanislavas Batys Gorskis - Lietuvos floros tyrinètojas. - Lietuvos TSR Aukštujų mokyklų Mokslo darbai. Biologija, 8: 5-25.

Gollerbach M.M., Krassavina L.K., 1983: Opredelitel presnovodnyx vodoroslej SSSR. Xarovye vodorosli - Charophyta, 14. - Leningrad.

GoRsKi S.B., 1830: Botanische bemerkungen. - In: Eichwald E. (ed.), Naturhistorische Skizze von Lithauen, Volhynien und Podolien: 105-180. Wilna.

Gorski S.B., 1849: Icones Potamogetonum, Characearum, Cyperacearum et graminearum novas vel minus cognitas species Lithuaniae illustrantes. Berlin.

Gregor T., RaAbe U., Van RaAm J., 2012: Typification of Nitella gracilis (Sm.) C. Agardh var. confervacea Brébisson ( $=N$. confervacea (Brébisson) A.Braun ex Leonhardi) with remarks on its nomenclatural history. - Cryptogamie Algologie, 33(4): 391-398.

Gregor T., Blindow I., Raabe U., Schubert H., Stewart N., 2014: (2303) Proposal to conserve the name Chara hispida (Characeae) with a conserved type. - Taxon, 63(4): 933-934.

Guiry M.D., Guiry G.M., 2021: AlgaeBase. Worldwide electronic publication, National University of Ireland, Galway. - http://www.algaebase.org [accessed 31 May 2021.

HRYNIEWIECKI B., 1959-1960: Gorski Stanislaw Batys. Polski Slownik Biografichny, 8. - Wroclaw-Krakow-Warszawa.
IUCN, 2012: Guidelines for Application of IUCN Red List Criteria at Regional and National Levels. Version 4.0. - Gland-Cambridge.

IUCN, 2017: Guidelines for Using the IUCN Red List Categories and Criteria. Version 14.-GlandCambridge.

Jorda C., Becker R., 2016: Chara strigosa. - In: Armleuchteralgen. Die Characeen Deutschlands. (Arbeitsgruppe Characeen Deutschlands Lehrstuhl für Ökologie der Universität Rostock, Eds), 336-345. - Berlin-Heidelberg.

JunDZILE S.B., 1791: Opisanie roślin w provincyi W.K. Litewskiego naturalnie rosnących, według układu Linneusza. - Wilno.

JunDziŁŁ J., 1822: Trzy poźnieysze raporta pana Jozefa Jundziłła do fakultetu fizyczno-matematycznego w uniwersytecie Imperatorskim Wilenskim, przyslane z poddrožy botanicznej do gubernii Wilenskiey. - Pamiętnik Farmaceutyczny Wilenski, 2(3): 574-587.

Jundzile J., 1830: Opisanie roślin w Litwe, na Wolyniu, Podolu i Ukraine dziko rosnących, jako i osvojonych. - Wilno.

Korsch H., 2016: Nitella gracilis. - In: Armleuchteralgen. Die Characeen Deutschlands. (Arbeitsgruppe Characeen Deutschlands Lehrstuhl für Ökologie der Universität Rostock, eds): 435443. - Berlin-Heidelberg.

Korsch H., 2018: The worldwide range of the Charophyte species native to Germany. - Rostocker Meeresbiologische Beiträge, 28: 45-96.

KostkevičIEnĖ J., SinkeviČIEnĖ Z., 2008: A preliminary checklist of Lithuanian macroalgae. - Botanica Lithuanica, 14(1): 11-27.

Krause W., 1997: Süßwasserflora von Mitteleuropa. Charales (Charophyceae), 18. - Jena-StuttgartLübeck-Ulm.

LANGANGEN A., 2007: Kransalger og deres forekomst i Norge - Oslo.

Langangen A., Koistinen M., Blindow I., 2002: The charophytes of Finland. - Memoranda Societatis pro Fauna Flora Fennica, 78: 17-48.

LEONHARDI H. VON, 1863: Ueber die böhmischen Characeen. - Lotos, 13: 55-62, 69-80.

Luther H., 1979: Chara connivens in the Baltic Sea area. - Annales Botanici Fennici, 16: 141-150.

Mardosaitė E., Minkevičius A., 1958: Dusios, Metelio ir Obelijos ežerų makrofitų bentosas ir fito- 
planktonas. - Lietuvos TSR MA Biologijos instituto darbai, 3: 55-72.

Matuszkiewiczowna J., 1953: Glony Wilna i najblizszych okolic. - Prace Towarzystwa Przyjaciol Nauk W Wilnie. Wydzial Nauk Matematycznych i Przyrodnycznych, 9: 263-277.

Meyen F.J.F., 1827: Beobachtungen und Bemerkungen über die Gattung Chara. - Linnaea, 2(1): 55-81.

MinkEviČIUs A., 1954: Daugų ežero sporinių augalų bentosas ir fitoplanktonas. - Vilniaus valstybinio universiteto mokslo darbai, 2: 157-172.

MinkeviČIUs A., TrainausKaité I., 1957: Trakų ežerų maurabraginiai dumbliai. - Vilniaus valstybinio universiteto mokslo darbai. Biologijos, geografijos ir geologijos mokslų serija, 12(4): 5-17.

MinkEviČIUS A., PIPINYs J., 1959: Kuršių marių floros ir augalijos apžvalga. - In: JANKEVIČIUS K. (ed.), Kuršių Marios, 109-133. - Vilnius.

MinkevičIUs A., Trainauskaitė I., 1970: S. Gorskio maurabragainių (Charophyta) rinkinys Vilniaus valstybiniame V. Kapsuko universitete. - Lietuvos TSR aukštujjų mokyklų mokslo darbai. Biologija, 10: 5-13.

Mowszowicz J., 1947: Characeae Wilna i jego okolic. - Acta Societatis Botanicorum Poloniae, 18(2):1-8.

Mowszowicz J., 1957: Conspectus florae Vilnensis. Część I. - Łódź.

Patzolt F., Korte E., Blindow I., 2016: Nitella confervacea. - In: Armleuchteralgen. Die Characeen Deutschlands. (Arbeitsgruppe Characeen Deutschlands Lehrstuhl für Ökologie der Universität Rostock, eds): 413-420. - Berlin-Heidelberg.

PlokšTiené D., 2002: Kuršių marių augalijos vystymasis ir kaita. - Jūra ir aplinka, 2(7): 33-41.

Romanov R., 2019: New interesting records of charophytes (Charales, Charophyceae) from Eurasia and Africa. - Webbia, 74(1): 159-166.

Romanov R., Napolitano T., van de Weyer K., Troia A., 2019: New records and observations to the Characean (Charales, Charophyceae) flora of Sicily (Italy). - Webbia, 74(1): 111-119.

Romanov R., Korolesova D., Afanasyev D., ZhakoVA L., 2020: Chara baltica (Charophyceae, Charales) from the Black Sea region and taxonomic implications of extrastipulodes. - Botanica, 26(2): 126-137.
Ruprecht F.J., 1845: Symbolae ad historiam et geographiam plantarum Rossicarum. - St. Peterburg.

Schubert H., Blindow I. (eds), 2003: Charophytes of the Baltic Sea. - Ruggel.

Schubert H., Blindow I., van de Weyer K., 2016a: Chara baltica. - In: Armleuchteralgen. Die Characeen Deutschlands. (Arbeitsgruppe Characeen Deutschlands Lehrstuhl für Ökologie der Universität Rostock, eds): 236-247. - Berlin-Heidelberg.

Schubert H., Blindow I., vAN DE Weyer K., 2016b: Chara papillosa. - In: Armleuchteralgen. Die Characeen Deutschlands. (Arbeitsgruppe Characeen Deutschlands Lehrstuhl für Ökologie der Universität Rostock, eds): 326-336. - BerlinHeidelberg.

Simons J., NAt E., 1996: Past and present distribution of stoneworts (Characeae) in The Netherlands. Hydrobiologia, 340: 127-135.

SINKEVIČIENĖ Z., 1994: Maurabraginiai dumbliai. - In: RAšomavičıus V. (ed.), Aukštadvario apylinkių augmenija: 17-19. - Vilnius.

SINKEVIČIENĖ Z., 1996: Nauja atžalinio dumblabragio (Tolypella prolifera) radimvietė Lietuvoje. - Botanica Lithuanica, 2(4): 411-413.

SinkeviČIENĖ Z., 2004: Charophyta of the Curonian Lagoon. - Botanica Lithuanica, 10(1): 33-57.

SINKEVIČIENĖ Z., 2007: Maurabragūnai CharophytaIn: Rašomavičıus V. (ed.), Lietuvos raudonoji knyga: 278-288. - Kaunas.

SINKEVIČIENĖ Z., 2010: Morphological variation in $L y$ chnothamnus barbatus (Meyen) Leonh. in Lake Balsys (Lithuania). - Charophytes, 2(1): 25-30.

SinkEvičIENĖ Z., 2019: Peculiarities of Chara filiformis (Charales, Charophyceae) distribution and oospore sizes in Lithuania. - Webbia, 74(1): 133-138.

SinkEviČIENĖ Z., 2021. Maurabragūnai Charophyta. - In: RašomaviČIUS V. (ed.), Lietuvos raudonoji knyga. Gyvūnai, augalai, grybai: 311-316. Vilnius.

SinkeviČIEnè Z., Urbaitė-MAŽEvič N., 2012: Lychnothamnus barbatus (Meyen) Leonh. in shallow Lake Šventininkai (Lithuania) - rediscovered after 50 years. - Biodiversity: Research and Conservation, 25: 91-96.

SinkeviČIené Z., BuČas M., Ilginė R., Vaičiūtė D., 
Kataržytė M., PetkuvienĖ J., 2017: Charophytes in the estuarine Curonian Lagoon: are there changes in diversity, abundance, and distribution since the late 1940s? - Oceanological and Hydrobiological Studies, 46(2): 186-198.

STEPANAVIČIENĖ V., 2000: Vilniaus miesto ežerų floros apžvalga. - Botanica Lithuanica, 6(3): 271-279.

Sugier P., Pelechaty M., Gabka M., Owsianny P.M., Pukacz A., Ciecierska H., Kolada A., 2010. Lychnothamnus barbatus: global history and distribution in Poland. - Charophytes, 2(1): 19-24.

ŠARKINIENE I., 1961: Rytų ir Pietų Lietuvos TSR ežerų makrofitu floristinè geografinè ir morfologinèekologinè analizè. - Lietuvos TSR aukštuju mokyklų mokslo darbai. Biologija, 1: 159-194.

ŠARKINIENE I., 1963: Rytų ir Pietų Lietuvos TSR ežerų makrofitinès augalijos apžvalga. - Lietuvos TSR Aukštujjų mokyklų mokslo darbai. Biologija, 3: 161-185.

ŠARKINIENE I., 1968: Makrofitnaja flora i rastitel'nost' ozera Žuvintas. - In: Zapovednik Žuvintas: 5883. - Vilnius.

ŠARKINIENE I., 1969: Svarbesniųų Žeimenos upès baseino pramoninių ežerų augalijos charakteristika. - Geografinis metraštis, 10: 105-121.

ŠARKINIENE I., 1970: Čerty makrofitnoj rastitel'nosti ozer i vodoxranilišč Litovskoj SSR. - Biologija ozer, 125-135. - Vilnius.

ŠARKINIENE I., 1971: Kauno vandens saugyklos makrofitai. - Lietuvos TSR aukštujų mokyklų mokslo darbai. Biologija, 11: 15-20.

ŠARkinienĖ I., Trainauskaité I., 1973: Ekologija xarovyx vodoroslej Litovskoj SSR. - In: Xarovye vodorosli i ix ispol'zovanie $\mathrm{v}$ issledovanii biologičeskix processov kletki: 104-118. - Vilnius.

ŠArkiniené I., Trainauskaité I., 1993: Sovremennoe sostojanie vodnoj makrofitnoj rastitel'nosti oz. Žuvintas. - In: Zapovednik Žuvintas: 208-214. Vilnius.

Teppke M., Blindow I., 2016: Chara aspera. - In: Armleuchteralgen. Die Characeen Deutschlands. (Arbeitsgruppe Characeen Deutschlands Lehrstuhl für Ökologie der Universität Rostock, eds), 227-236. - Berlin-Heidelberg.

TORn \& MARTIN, 2003: Chara vulgaris L. 1753. - In: Schubert H., Blindow I. (eds), Charophytes of the Baltic Sea, 149-155. - Ruggel.
Torn K., Martin G., Munsterhuelm R., 2003: Chara tomentosa L. 1753. - In: Schubert H., Blindow I. (eds), Charophytes of the Baltic Sea: 131-141. Ruggel.

Torn K., Kovtun-Kante A., Herkül K., Martin G., MÄEMETS H., 2015: Distribution and predictive occurrence model of charophytes in Estonian waters. - Aquatic Botany, 120: 142-49.

Trainauskaitė I., 1970: Xarovye vodorosli (Charophyta) v vodoëmax Litovskoj SSR (Avtoreferat dissertacii). - Vilnius.

TrainAuSKaitè I., 1978: Vodnaja rastitel'nost' zaliva Kuršių marios. - In: Fiziologobioximičeskie osnovy rasvitija planktonnyx organizmov $\mathrm{v}$ severnoj časti zaliva Kuršių marios: 61-73. - Vilnius.

Trainauskaité I., 1987: Makrofity. - In: Sostojanie gidrobiocenozov vodoëma-oxladitelja Ignalinskoj AE do načala ee ekspluatacii: 19-30. - Vilnius.

TrainauskaitĖ I., 1992: Maurabragiai. - In: BalevičIus K. (ed.), Lietuvos Raudonoji knyga, 311-314. - Vilnius.

Trainauskaité I., Vasiliauskiené M., Šarkiniené I., MockutE A., 1977: Rasprostranenie, flora i biomasa makrofitov. - In: Hidrobiologičeskie isledovanija ozer Dusia, Galstas, Šlavantas, Obelija: 43-70. - Vilnius.

Trbojević I., Milovanović V., Subakov Simić G., 2020: The discovery of the rare Chara baueri (Charales, Charophyceae) in Serbia. - Plants, 9(11): 1606. https://doi.org/10.3390/plants9111606

UrbaniaK J., 2003: Tolypella nidifica (O.F. Müll.) A.Braun 1856. - In: Schubert H., Blindow I. (eds), Charophytes of the Baltic Sea, 223-233. Ruggel.

Urbaniak J., GĄBKa M., 2014: Polish charophytes. An illustrated guide to identification. - Wroclaw. VAN DE Weyer K., 2016: Tolypella prolifera. - In: Armleuchteralgen. Die Characeen Deutschlands. (Arbeitsgruppe Characeen Deutschlands Lehrstuhl für Ökologie der Universität Rostock, eds): 539-546. - Berlin-Heidelberg.

Vishnyakov V.S., Romanov R. E., Komarova A.S., Belyakov E.A., Moseev D.S., Churakova E.Yu., Czhobadze A.B., Philippov D.A., 2021: Novye naxodki xarovyx vodoroslej (Characeae) v Evropejskoj Rossii. - Botaničeskij Žurnal, 106(1): 61-76. 
WolfGang J.F., 1822: Wiadomości o świezo odkrytych lub rzadszych roślinach przybyłych do flory Litewkey w r.1821. - Pamietnik Farmaceutyczny Wilenski, 2: 649-653.

WolfGANG J.F., 1824: Wiadomośći o nowo przy- byłych roślinach do flory Litewskiey w r. $1822 \mathrm{i}$ 1823. - Dziennik medicyny, chirurgii i farmacii, 2: 647-656.

Zviedre E., Deķere Z., 2005: Mieturalıgúu sugu nosaukumi un termini latviešu valodā. - Acta Universitatis Latviensis. Biology, 691: 145-155.

\section{CHARACEAE (CHARALES, CHAROPHYCEAE) RŪŠIŲ IR JŲ PAPLITIMO LIETUVOJE REVIZIJA}

\section{Zofija SinkevičıenĖ, Zigmantas GudžInSKAS}

\section{Santrauka}

Atlikus herbariumo pavyzdžių, surinktų nuo XIX a. pradžios, reviziją, patvirtinta, kad Lietuvoje aptinkama 21 maurabraginių (Characeae) šeimos dumblių rūšis. Jos priklauso penkioms gentims: $C h a-$ ra (12 rūšių), Nitella (5 rūšys), Tolypella (2 rūšys), Lychnothamnus ir Nitellopsis (po 1 rūšį). Trylika rūšių, paminètų herbariumo pavyzdžių etiketèse ir kituose šaltiniuose, nebuvo patvirtintos. Characeae rūšių paplitimas buvo užfiksuotas 251 geografinio tinklo kvadrate (42 proc. kvadratų iš visų 593 kvadratų). Analizuoti herbariumo pavyzdžiai surinkti 693 vandens telkiniuose, daugiausia ežeruose. Chara globularis yra Lietuvoje labiausiai paplitusi rūšis, užregistruota 150-yje tinklo kvadratų ir daugiau kaip 250-yje vandens telkinių. Dešimt rūšių (Chara aspe- ra, C. contraria, C. filiformis, C. subspinosa, C. tomentosa, C. virgata, C. vulgaris, Nitella mucronata, N. flexilis, Nitellopsis obtusa) yra užregistruotos nuo 100 iki 50 kvadratų ir taip pat priskirtinos prie dažnų rūšių. Chara papillosa ir C. strigosa buvo užregistruotos kiek mažiau negu 50-yje kvadratų ir gali būti priskiriamos prie gana dažnų rūšių. Aštuonios rūšys (Chara baltica, C. canescens, Lychnothamnus barbatus, Nitella confervacea, N. gracilis, N. syncarpa, Tolypella nidifica, T. prolifera) užregistruotos dešimtyje ar mažiau kvadratų ir priskiriamos prie retų arba labai retų rūšių grupès. Straipsnyje taip pat aptariamos rūšys, kurių vardai minimi literatūros šaltiniuose arba įrašyti herbariumo pavyzdžių etiketėse, tačiau jų buvimas Lietuvoje nepasitvirtino. 